Review

\title{
Bioinorganic chemistry of copper coordination to alpha-synuclein: Relevance to Parkinson's disease
}

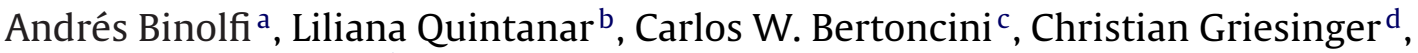 \\ Claudio O. Fernández ${ }^{\mathrm{d}, \mathrm{e}, *}$ \\ a Department of NMR-assisted Structural Biology, In-cell NMR, Leibniz Institute of Molecular Pharmacology (FMP), Robert-Roessle-Str. 10, 13125 Berlin, Germany \\ ${ }^{\mathrm{b}}$ Centro de Investigación y de Estudios Avanzados (Cinvestav), Av. Instituto Politécnico Nacional 2508, 07360 D.F., Mexico \\ ${ }^{\mathrm{c}}$ Institute for Research in Biomedicina Barcelona, Baldiri Reixac 10, 08028 Barcelona, Spain \\ d Department of NMR-based Structural Biology, Max Planck Institute for Biophysical Chemistry, Am Fassberg 11, D-37077 Göttingen, Germany \\ e Instituto de Biología Molecular y Celular de Rosario, Consejo Nacional de Investigaciones Científicas y Técnicas (IBR-CONICET), Universidad Nacional de Rosario, \\ Suipacha 531, S2002LRK Rosario, Argentina
}

\section{Contents}

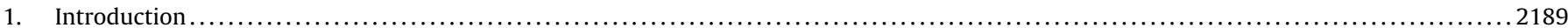

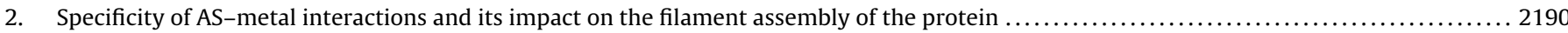

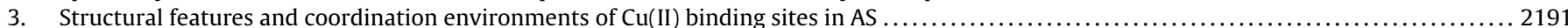

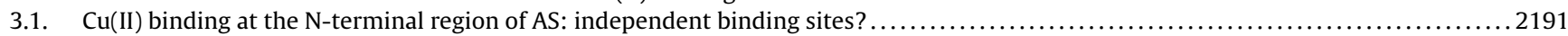

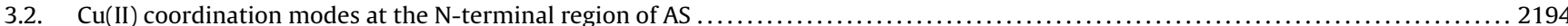

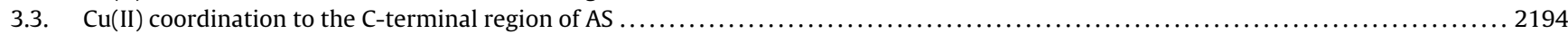

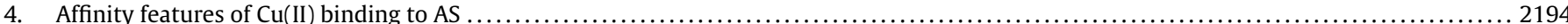

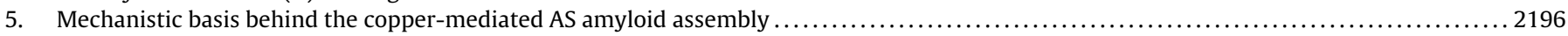

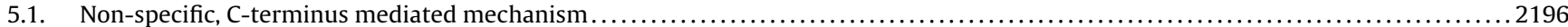

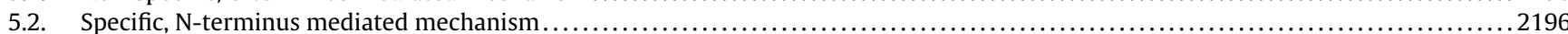

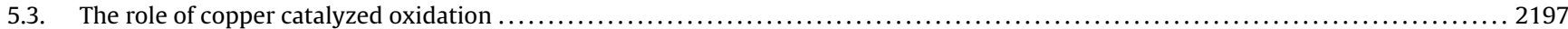

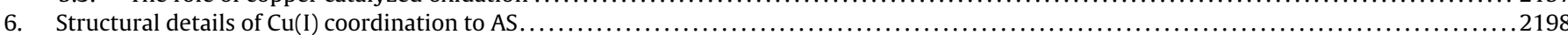

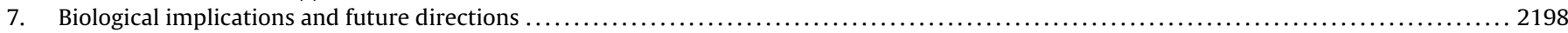

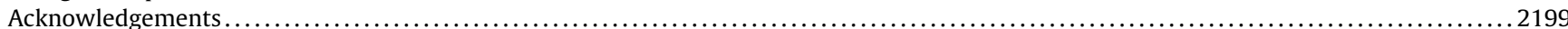

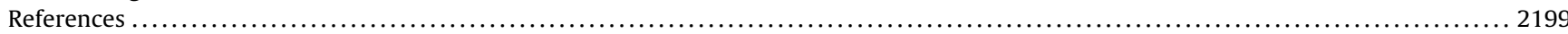

\section{A R T I C L E I N F O}

\section{Article history:}

Received 22 January 2012

Accepted 7 May 2012

Available online 14 May 2012

\section{Keywords:}

Alpha-synuclein

Copper

Coordination chemistry

Oxidative-damage

Neurodegeneration

\begin{abstract}
A B S T R A C T
Alpha-synuclein (AS) aggregation is associated with neurodegeneration in Parkinson's disease (PD). At the same time, alterations in metal ion homeostasis may play a pivotal role in the progression of AS amyloid assembly and the onset of PD. Elucidation of the structural basis directing AS-metal interactions and their effect on AS aggregation constitutes a key step toward understanding the role of metal ions in AS amyloid formation and neurodegeneration. This work provides a comprehensive review of recent advances attained in the bioinorganic chemistry of AS amyloid diseases. A hierarchy in AS-metal ion interactions has been established: while the physiologically relevant divalent metal ions iron and manganese interact at a non-specific, low-affinity binding interface in the C-terminus of AS, copper binds with high affinity at the $\mathrm{N}$-terminal region and it is the most effective metal ion in accelerating AS filament assembly. The strong link between metal binding specificity and its impact on aggregation is discussed here on a mechanistic basis. A detailed description of the structural features and coordination environments of copper to AS is presented and discussed in the context of oxidative cellular events that might lead to the development of PD. Overall, the research observations presented here support the notion that perturbations in copper metabolism may be a common upstream event in the pathogenesis of neurodegenerative processes.
\end{abstract}

(C) 2012 Elsevier B.V. All rights reserved.

\footnotetext{
* Corresponding author at: Instituto de Biología Molecular y Celular de Rosario, Consejo Nacional de Investigaciones Científicas y Técnicas (IBR-CONICET), Universidad Nacional de Rosario, Suipacha 531, S2002LRK Rosario, Argentina. Tel.: +54 341 4448745; fax: +54 3414390465 .

E-mail addresses: fernandez@ibr.gov.ar, cfernan@gwdg.de (C.O. Fernández).
} 


\section{Introduction}

The misfolding of proteins into a toxic conformation is proposed to be at the molecular foundation of a number of neurodegenerative disorders including Prion's, Alzheimer's (AD) and Parkinson's diseases (PD) [1]. One common and defining feature of protein misfolding diseases is the formation and deposition of protein aggregates in various morphologies, including amyloid fibrils [2]. The most prominent amyloid disease is $\mathrm{AD}$, whereas $\mathrm{PD}$ is the second most common neurodegenerative disorder, affecting nearly 10 million people worldwide [2,3]. Neurodegeneration in PD is progressive and is characterized by the loss of dopaminergic neurons in the substantia nigra, and the presence of amyloid fibrillar cytoplasmic aggregates, known as Lewy bodies, in multiple brain regions, containing the protein $\alpha$-synuclein (AS) [4-7]. $\alpha$-Synuclein is a highly soluble, intrinsically disordered protein, predominantly synthesized in the neurons of the central nervous system and localized at presynaptic terminals in close proximity to synaptic vesicles. Evidence that AS amyloidogenesis plays a causative role in the development of PD is furnished by a variety of genetic, neuropathological and biochemical studies: (i) it is the main component of neuronal and glial cytoplasmatic inclusions, the pathological hallmarks of PD, dementia with Lewy bodies (DLB), multiple system atrophy (MSA) and other neurodegenerative disorders collectively referred to as synucleinopathies [6-8]; (ii) three point mutations in the AS gene (A53T, A30P, E46K) are linked to early onset familial PD [9-11], whereas genome-wide association studies reveals genetic risk underlying PD [12,13] and (iii) transgenic animal models involving overexpression of AS develop cytoplasmatic inclusions and motor deficiencies [14-17].

$\alpha$-Synuclein comprises 140 amino acid residues distributed in three different regions (Fig. $1 \mathrm{~A}$ ): the $\mathrm{N}$-terminal region, which encompasses residues $1-60$, includes imperfect repeats KTKEGV and is involved in lipid binding [18-20]; the highly hydrophobic self-aggregating sequence known as NAC (non-amyloid- $\beta$ component, residues 61-95), which initiates fibrillation [21]; and the acidic C-terminal region, rich in Pro, Asp and Glu amino acids, which encompasses residues $96-140$ and is essential for blocking rapid AS filament assembly [22-24]. In its monomeric, intrinsically disordered state, the protein is best described as an ensemble of structurally heterogeneous conformations, with no persistent secondary structure and with long-range inter-residue interactions that stabilize aggregation-autoinhibited conformations
[25-28]. These intramolecular contacts in AS are mainly established between the C-terminus and the NAC region (hydrophobic interactions), and between the $\mathrm{C}$ - and $\mathrm{N}$-terminal region (electrostatic interactions) (Fig. 1B) [25-27]. More recently, it has been proposed that AS occurs physiologically as a helically folded tetramer, and that destabilization of this metastable tetramer precedes aberrant aggregation of AS monomers in tissue [29,30]. However, another work argued strongly against this hypothesis, supporting the fact that AS would exist physiologically as an unfolded monomer [31]. Overall, the mechanism(s) underlying the structural transition from the innocuous "native" state of AS to its aggregated form still remain uncertain.

The physiological role of AS has been related to membrane binding and synaptic vesicle recycling, and it has been hypothesized that intracellular AS may associate with the plasma and vesicular membranes [32-34]. When associated with lipid surfaces or micelles, the $\mathrm{N}$-terminal of AS adopts an $\alpha$-helical conformation $[35,36]$. Misfolding of AS may impair its ability to associate to membranes, causing its accumulation in the cytosol, and promoting its oligomerisation and aggregation in vivo. On the other hand, AS function has also been linked to dopamine metabolism, as AS seems to interact with proteins that regulate dopamine synthesis and uptake [37]. $\alpha$-Synuclein alters the activity of tyrosine hydroxylase [38], a key enzyme in dopamine synthesis; and it also inhibits aromatic amino acid decarboxylase, which regulates the conversion of L-dopa into dopamine [39]. Interestingly, AS neurotoxicity seems to be dopamine dependent: AS causes apoptosis in cultured human dopaminergic neurons, while it exhibits a neuroprotective effect in nondopaminergic human cortical neurons [40]. These links between dopamine and AS might account for the selective neuronal loss in PD. Finally, more recent studies point toward the involvement of AS in rescuing lethality associated with the lack of CSP $\alpha$ protein, a co-chaperone associated with synaptic vesicles and implicated in the folding pathways of SNARE proteins, suggesting that AS might act as an auxiliary chaperone preserving the function and integrity of synapses [32,33].

Although it remains unclear how AS can initiate neuronal death, it is certain that the amyloid aggregation of AS is essential for the pathological effects associated with PD. The mechanism of AS filament assembly is characterized by the formation of $\beta$-sheet rich pre-fibrillar, oligomeric aggregates of heterogeneous size and morphology that includes spheres, chain-like structures, annular pore-like structures, and large granular structures [41,42]. Initially,

(A)

1 MDVFMKGLSKAKEGVVAAAEKTKQGVAEAAGKTKEGVLYVGSKTKEGVVH $\mathbf{5 0}$ 51 GVATVAEKTKE QVTNVGGAVVT GVTAVAQKTVE GAGS IAAAT GFVKKDQL 100 101 GKNEEGAPQEGILEDMPVD PDNEAYEMPSEEGYQDYEPEA

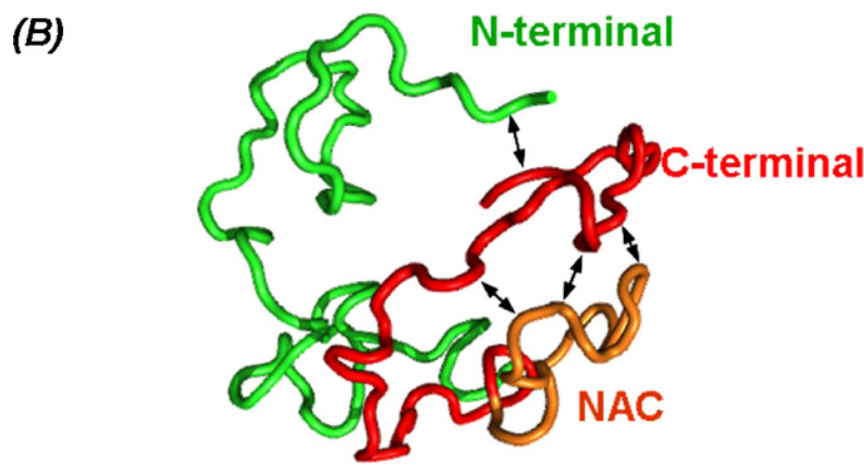

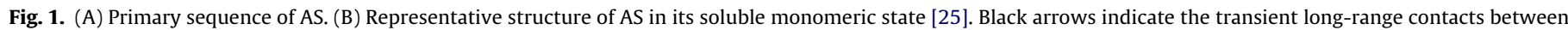

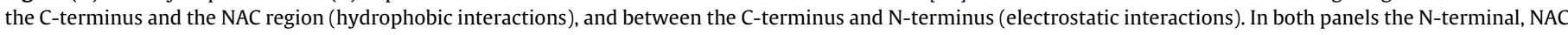
and $\mathrm{C}$-terminal regions are identified in green, orange and red, respectively. 
the amyloid hypothesis implicated AS amyloid fibrils as the main cause for neurodegeneration in PD. However, recent research suggests that oligomers and prefibrillar intermediates might be the neurotoxic species of AS $[41,43,44]$. A common proposal for the mechanism of oligomeric AS neurotoxicity involves the formation of pores in membranes, which in turn causes cell permeability, calcium influx and apoptosis [45]. The neurotoxic effect might be dependent on the nature of AS oligomers, which in turn may vary depending on cellular conditions. Recent evidence suggest that amyloidogenic proteins such as AS may exert its neurotoxic function via sequestration of essential cellular proteins in the process of fibrillation [46].

Even if amyloid assembly is a complex and multifaceted process, the dominant risk factor associated with PD and other neurodegenerative diseases is increasing age. Several studies indicate that one of the consequences of normal aging is a rise in the levels of copper and iron in brain tissue. The brain is an organ that concentrates metal ions, and there is now increasing evidence that a break-down in metal homeostasis may be a key factor in a variety of age-related neurodegenerative diseases $[47,48]$. As discussed extensively in other chapters of the present issue, copper and to a lesser extent manganese have been implicated in Prion's diseases [49-52], whereas recent studies emphasize the role of copper, iron and zinc as contributors to both, amyloid- $\beta(A \beta)$ assembly in vitro and the neuropathology of AD [50,53-56]. High levels of copper, zinc and iron were also found in and around amyloid plaques of AD brains [57]. Furthermore, coordination environments for copper complexes in the amyloid precursor protein, the $A \beta$ peptide and the prion protein have been very well characterized by several biophysical and structural studies [51-54,58-74]. Recently, detailed knowledge of the structural and binding features of relevant metal ions as well as the mechanism by which these metal ions might participate in the aggregation of these proteins have contributed to the design of new therapeutical schemes based on the development of metal ion chelators $[75,76]$.

The role of metal ions in AS amyloid assembly and neurodegeneration is also becoming a central question in the pathophysiology of PD. The involvement of metal ions in PD was first proposed based on the fact that iron, zinc and aluminum concentrations in the subtantia nigra of PD patients are higher than those of control tissues [77]. Iron deposits have also been identified in Lewy bodies [78] and elevated copper concentrations were found in the cerebrospinal fluid of PD patients [79]. Experiments using animals also demonstrated that the unilateral injection of iron into the substantia nigra resulted in substantial selective decrease in striatal dopamine, supporting the assumption that iron initiates dopaminergic neurodegeneration in PD [80]. Direct injection of copper in the nigrostriatal system of rats showed that this metal ion seems to induce degeneration by destroying the antioxidant defenses and promoting apoptosis $[81,82]$. Furthermore, epidemiological research indicates that individuals with chronic exposure to copper, manganese or iron display an increased rate of PD [83], whereas a systematic analysis of the effect of various metal ions revealed that iron, copper, manganese and aluminum are the most effective ions in promoting AS filament assembly in vitro [84-86].

Despite the research discussed above, the mechanism through which different metal ions promote AS aggregation is still elusive, as is their exact role in the molecular mechanisms that lead to neurodegeneration and development of PD. Several possible processes for metal-enhanced AS aggregation can be envisaged within this regard. The simplest one would involve the formation of AS-metal complexes resulting in structural changes that would generate protein species with an increased propensity to aggregate, such as oligomeric intermediate species. Alternatively, oxidative stress has been proposed to be involved in the pathogenesis of several neurodegenerative disorders. Increasing oxidative stress and reduction in antioxidant defense occur in the substantia nigra of PD patients [87]. In particular, dopamine oxidative metabolism and generation of hydrogen peroxide have been observed in PD brain [88] Additionally, iron, copper and free radical generators stimulate the production of intracellular aggregates containing AS [89-95]. Although the physiological concentrations of metals, the composition of the cytosol, and the redox states accessible to the different metal ions may lead to more complex scenarios, the evidences discussed here indicate that AS-metal interactions play a role in protein aggregation, and they are likely to provide a link between the accumulation of aggregated proteins, oxidative damage in the brain and neuronal cell death.

In summary, the notion that metal ions may be involved in the progression of AS filament assembly and neurodegeneration in PD raises essential questions: What is the effect of metal ions on AS aggregation kinetics? Is there any specificity for AS-metal interactions and their impact on AS amyloid formation? What are the structural determinants and affinity features underlying these AS-metal interactions? What is the mechanistic basis behind the effects of metal ions on AS amyloid assembly? In order to effectively understand the role of metal ions in AS aggregation and in neurodegenerative pathways leading to $\mathrm{PD}$, these questions must be addressed.

This knowledge is crucial to establish the role of metal ions in synucleinopathies and to address the central question of whether these agents constitute a common denominator underlying the amyloid-related disorders known as AD, PD, and prion diseases. The main objective of this work is to discuss the significant advances made in the bioinorganic chemistry of PD in the last decade, illustrating how the fields of coordination chemistry, biophysics and structural biology have been combined successfully to study crucial AS-metal interactions that lie at the molecular origin of a major neurological disease as PD.

\section{Specificity of AS-metal interactions and its impact on the filament assembly of the protein}

As mentioned above, a number of epidemiological and biochemical studies have linked exposure to heavy metals or perturbations in metal ion metabolism to the onset of neurodegeneration, including PD pathogenesis $[77,83]$. Soon after the discovery of AS as the major aggregated protein in Lewy bodies, several groups reported binding of metal cations to AS, as well as their effects in the formation of amyloid fibrils of the protein. In a seminal work, Uversky et al. demonstrated that a wide variety of metal cations in the millimolar range of concentrations interact with AS and affect its structural features [84]. The strongest structural impact was found upon binding of $\mathrm{Al}(\mathrm{III}), \mathrm{Cu}(\mathrm{II}), \mathrm{Fe}(\mathrm{III})$ and $\mathrm{Mn}(\mathrm{II})$, as characterized by circular dichroism (CD) spectroscopy and the binding signatures of the fluorophore 1,1'-bis(4-anilino)naphthalene-5,5'-disulphonic acid (bis-ANS), indicating that the protein would adopt a partially folded state, which would be more prone to aggregate than the protein in its monomeric state. Most of the tested cations showed a strong enhancement of the fibrillation rate of $\mathrm{AS}$, with $\mathrm{Al}(\mathrm{III}), \mathrm{Cu}(\mathrm{II})$, $\mathrm{Fe}(\mathrm{III})$ and $\mathrm{Mn}(\mathrm{II})$ among the most effective ones. The conformational changes and the enhancement of fibrillation were attributed to the binding of metal ions to the negatively charged carboxylate side-chains in the $\mathrm{C}$-terminal region of AS.

Other studies reported a strong influence of metal ions on the extent of oligomerization of AS and on the nature of the oligomeric species formed [96,97]. While $\mathrm{Cu}(\mathrm{II})$ and $\mathrm{Fe}(\mathrm{II})$ enhance the population of oligomeric intermediates without modifying the nature of AS oligomers, the rest of the tested metal ions produced a variety of oligomeric shapes without a significant enhancement of net oligomerization. Interestingly, $\mathrm{Ca}$ (II) and $\mathrm{Co}(\mathrm{II})$ produced high 


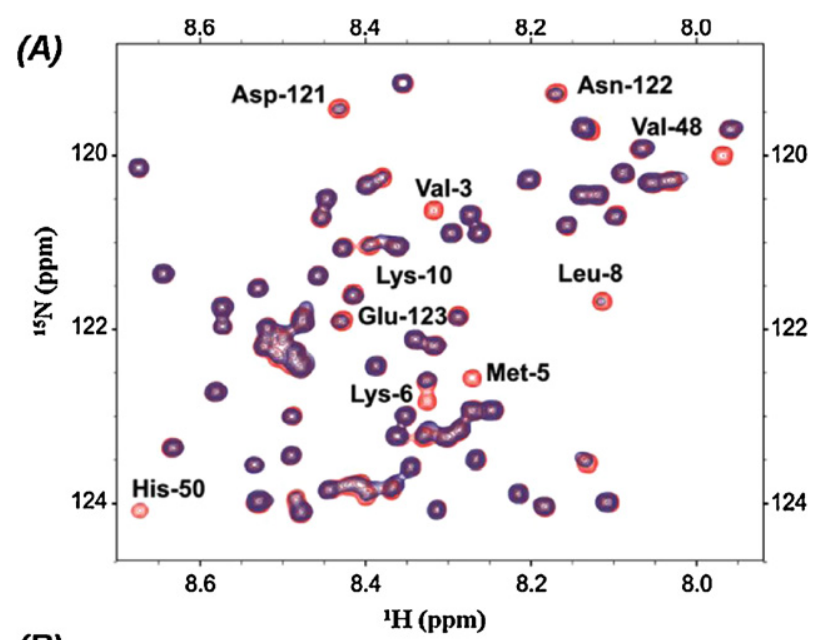

(B)

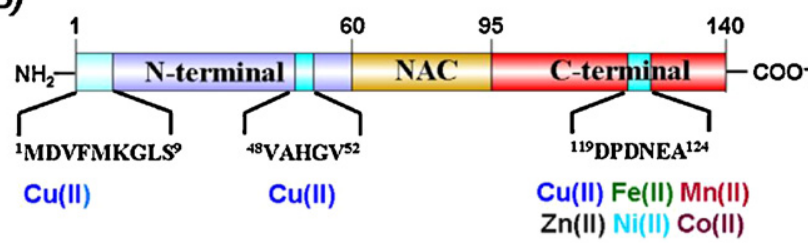

Fig. 2. Mapping of AS-metal interactions by NMR. (A) Overlaid ${ }^{1} \mathrm{H}-{ }^{15} \mathrm{NHSQC}$ spectra of AS in the absence (red) and presence (blue) of $\mathrm{Cu}(\mathrm{II})$. The NMR assignments of those backbone amide resonances affected significantly by the presence of the metal ion are indicated. (B) Metal binding regions in AS determined by NMR mapping experiments $[98,100,102,104,105]$.

amounts of annular "donut shaped" oligomers, now recognized as one of the most neurotoxic species of the protein $[42,43]$. These early results suggested that, despite the apparent lack of specificity for binding, the impact of metals on AS amiloidogenesis might be highly determined by the nature of the metal ion.

The effects of transition metal ions on AS fibrillation discussed above were examined mostly at concentrations in the millimolar range, far greater than those normally occurring in tissues [84,97], which obscures the physiological relevance that these effects might have on the etiology of the disease. Furthermore, those studies did not include a structural characterization of the metal binding sites, or the identification of the amino acids involved in the metal-AS interactions. The lack of biochemical, affinity and structural data at physiologically relevant conditions was the driving force that prompted subsequent research to address unresolved details related to the binding of metal ions to AS.

The binding sites and affinity features of the interaction of AS with metal cations have been determined only recently, at molecular resolution. First, a number of metal ion binding sites were ascribed to the C-terminus of the protein by means of deletion and mutagenesis studies [97]. The presence of several Asp and Glu residues in that domain confers a negative net charge of -14 that strongly attracts cations, suggesting that metal-induced oligomerization of AS is highly dependent on the C-terminal acidic region. Additionally, two-dimensional heteronuclear Nuclear Magnetic Resonance (NMR) spectroscopy allowed the identification of the amino acid residues involved in metal binding to this region of AS (Fig. 2). Although multiple metal binding sites were mapped at the C-terminal region, the primary binding site for divalent metal ions, such as $\mathrm{Fe}(\mathrm{II}), \mathrm{Mn}(\mathrm{II}), \mathrm{Cu}(\mathrm{II}), \mathrm{Zn}(\mathrm{II}), \mathrm{Co}(\mathrm{II})$ and $\mathrm{Ni}(\mathrm{II})$, is the ${ }^{119}{ }^{1}$ DPDNEA ${ }^{124}$ sequence (Fig. $\left.2 \mathrm{~B}\right)[98,99]$. The identified binding motif not only appears to have low specificity for metal cations, but it also displays low binding affinities $\left(K_{d} \sim 10^{-3} \mathrm{M}\right)$, as determined by NMR, UV-vis spectroscopy and equilibrium dialysis experiments $[98,100]$. The low affinity and lack of selectivity of the C-terminal

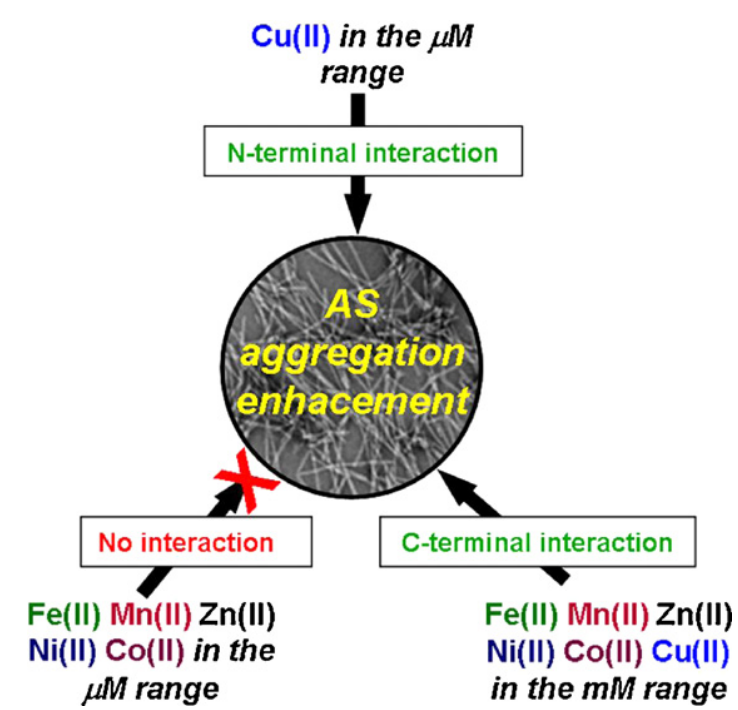

Fig. 3. Comparative diagram illustrating the binding preferences of different divalent metal ions and their effects on AS $(100 \mu \mathrm{M})$ aggregation enhancement. Metal concentrations in the micromolar range refers to $40-100 \mu \mathrm{M}$, while millimolar range refers to $0.5-5.0 \mathrm{mM}$.

region of AS challenge the biological relevance of metal ion interactions on this domain in the pathogenesis of PD.

In contrast to the $\mathrm{C}$-terminal binding region, the $\mathrm{N}$-terminal interface showed high specificity of binding for $\mathrm{Cu}(\mathrm{II})$ ions. Spurred by a battery of low and high-resolution techniques, two novel copper binding regions were identified initially at the N-terminus of the protein: ${ }^{1}$ MDVFMKGLS ${ }^{9}$ and ${ }^{48}$ VVHGV $^{52}$ [98,100-103] (Fig. 2A and $\mathrm{B}$ ), suggesting that $\mathrm{Cu}(\mathrm{II})$ binding to the $\mathrm{N}$-terminal region of $\mathrm{AS}$ may have a biologically relevant role in the onset of $\mathrm{PD}$. This notion is further supported by AS aggregation experiments using micromolar concentrations of metal ions, which showed that $\mathrm{Cu}(\mathrm{II})$ is the only metal ion that accelerates the formation of amyloid fibrils under these conditions $[98,100]$. These studies demonstrate conclusively that the effect of divalent metal ions on AS fibrillation is determined by their binding properties (Fig. 3). Moreover, the strong link between specificity of metal binding to AS and effectiveness in accelerating AS filament assembly reveals a hierarchy of AS-metal interactions that reflects both biological and structural effects. Overall, the specificity of copper binding to AS indicates that the mechanism through which $\mathrm{Cu}$ (II) impacts AS aggregation differs significantly from that exerted by other divalent metal ions. Such differences are likely to rise from structural effects associated with the nature of the coordinating moieties of the protein. Therefore, the coordination chemistry of copper binding to AS has deserved so much attention in the last few years, and it is the main subject of the present review.

\section{Structural features and coordination environments of $\mathrm{Cu}(\mathrm{II})$ binding sites in AS}

\section{1. $\mathrm{Cu}(\mathrm{II})$ binding at the $\mathrm{N}$-terminal region of AS: independent binding sites?}

The fact that $\mathrm{Cu}$ (II) binds specifically to the $\mathrm{N}$-terminal region of AS and it is the transition metal ion most effective in accelerating AS aggregation under physiological conditions underscores the importance of understanding the structural features of $\mathrm{Cu}(\mathrm{II})$ binding to AS. Using an approach that combines protein modification by diethyl pyrocarbonate (DEPC) and MALDI-TOF mass spectrometry, two $\mathrm{Cu}(\mathrm{II})$ anchoring sites at the $\mathrm{N}$-terminal region of AS were identified [104]. The comparison of AS and H50A AS 
(A)
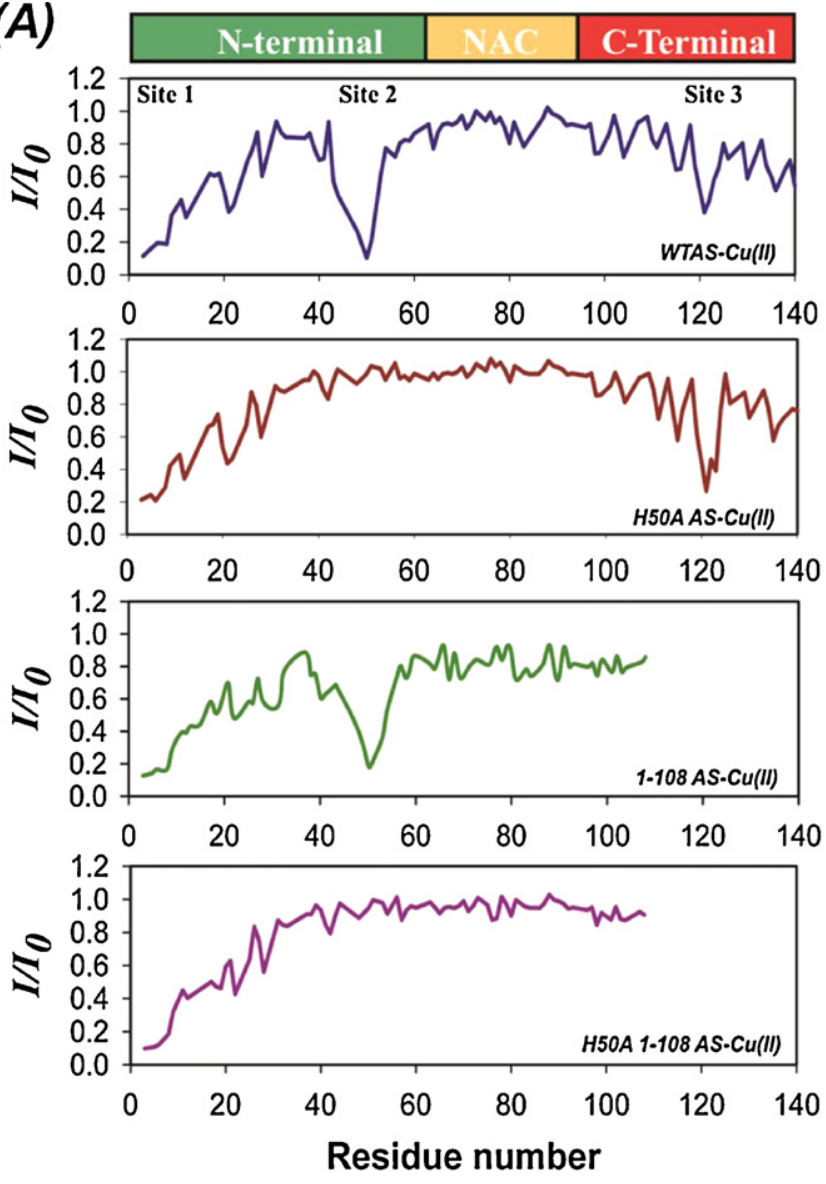

(B)
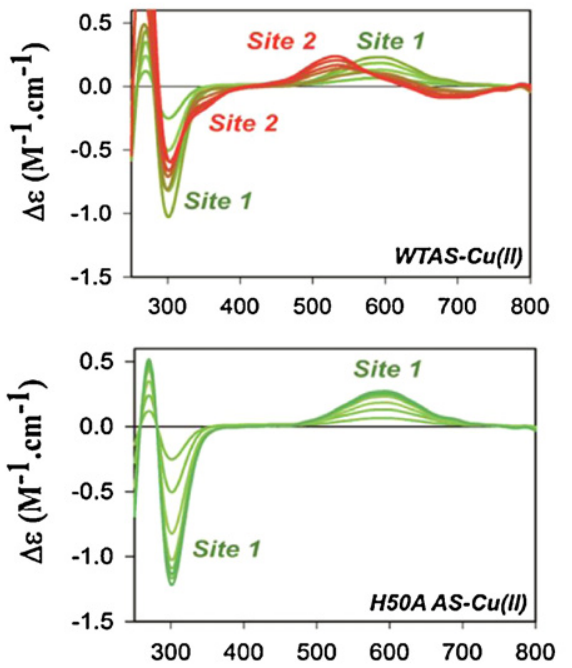

Wavelength (nm)
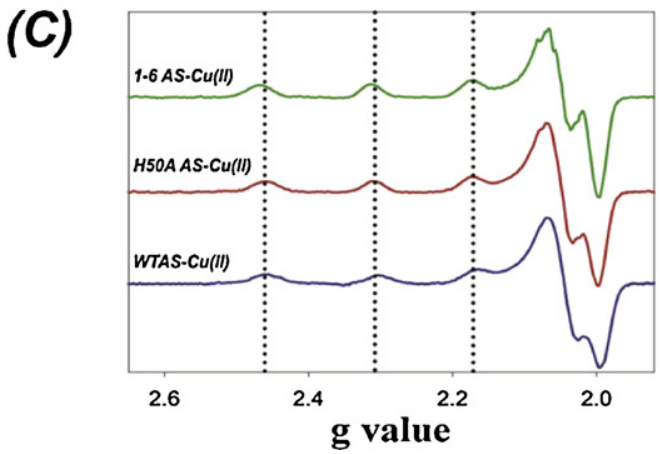

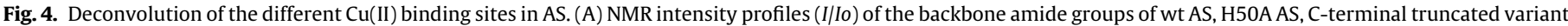

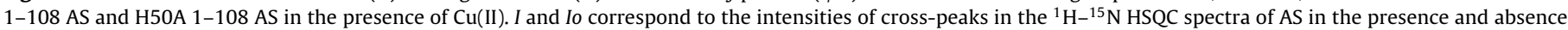

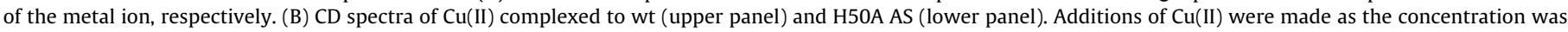

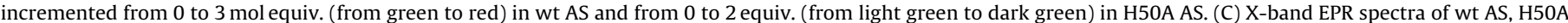
AS and ${ }^{1}$ MDVFMK $^{6}$ AS Cu(II) complexes at substoichiometric metal:protein (0.8:1.0) ratios.

demonstrated that the imidazole ring of His-50 is one of the $\mathrm{Cu}(\mathrm{II})$ anchoring residues; while collision induced dissociation MS/MS studies allowed one to unequivocally identify the free $\alpha-\mathrm{NH}_{2}$ group of Met- 1 in the sequence ${ }^{1}$ MDVFMK ${ }^{6}$ as the other $\mathrm{Cu}(\mathrm{II})$ anchoring site. These results were further confirmed by NMR spectroscopy at single residue resolution $[104,105]$. Comparison of ${ }^{1} \mathrm{H}-{ }^{15} \mathrm{~N}-\mathrm{HSQC}$ intensity profiles of AS and its H50A mutant species demonstrated that $\mathrm{Cu}(\mathrm{II})$ induces specific changes in the region containing His50 , and at the first residues of the sequence around Met-1 (Fig. 4A). In the H50A AS mutant, the effect of $\mathrm{Cu}(\mathrm{II})$ in the region around His-50 is abolished, while the broadening effect at the Met- 1 site is preserved, suggesting that the $\mathrm{Cu}(\mathrm{II})$ binding sites in AS constitute independent, non-interacting sites. Elimination of the C-terminal fragment in the 1-108 AS species did not perturb $\mathrm{Cu}$ (II) binding to Met-1, nor the His-50 site (Fig. 4A), indicating that the transient long-range interactions between the $\mathrm{C}$ - and $\mathrm{N}$-terminal regions of AS do not influence the binding preferences of the metal ion.

The notion of the independent nature of the $\mathrm{Cu}$ (II) binding sites at the N-terminus of AS is supported by $\mathrm{CD}$ and electron paramagnetic resonance (EPR) spectroscopy (Fig. 4B and C) [104,105]. A titration of $\mathrm{AS}$ with $\mathrm{Cu}(\mathrm{II})$ revealed that at low $\mathrm{Cu}$ :AS ratios ( $<1$ equiv.), the $C D$ spectrum is characterized by the presence of a positive $\mathrm{d}-\mathrm{d}$ transition band at $600 \mathrm{~nm}$ and a negative ligand to metal charge transfer (LMCT) band at $300 \mathrm{~nm}$, associated with an amide nitrogen coordinated to $\mathrm{Cu}$ (II) (Fig. 4B) [106,107]. Beyond 1 equiv. of $\mathrm{Cu}$ (II), the development of a positive band at $520 \mathrm{~nm}$ and of a negative ellipticity around $650 \mathrm{~nm}$ in the $\mathrm{d}-\mathrm{d}$ transition region, together with a LMCT band at $340 \mathrm{~nm}$ become evident and get saturated at 2 equiv. of metal. The $340 \mathrm{~nm}$ band falls in the range for $\pi 1$ imidazole nitrogen to $\mathrm{Cu}(\mathrm{II}) \mathrm{CT}[106,108,109]$. The second set of signals does not appear in the titration of H50A AS (Fig. 4B), that shows $\mathrm{CD}$ spectral features identical to those corresponding to the wt protein at sub-stoichiometric metal concentrations. These results demonstrate that the transitions at 600 and $300 \mathrm{~nm}$ reflect the coordination of $\mathrm{Cu}$ (II) to the binding site involving Met- 1 residue (site 1 hereafter), and that the signals at 520,650 and $340 \mathrm{~nm}$ arise from $\mathrm{Cu}$ (II) binding to His-50 (site 2 hereafter). On the other hand, EPR experiments revealed three different AS-Cu(II) species based on their parallel g values and metal hyperfine couplings [104,105]. Two of these species were associated with $\mathrm{Cu}(\mathrm{II})$ sites at the Nterminal region of the protein, and at sub-stoichiometric metal concentration the EPR spectra revealed one species with $g_{\|}=2.250$ and $A_{\|}=189 \times 10^{-4} \mathrm{~cm}^{-1}$. The same EPR parameters are observed for the H50A AS mutant and the synthetic peptide ${ }^{1}$ MDVFMK $^{6}$ (Fig. 4C), implying that the signal is associated with $\mathrm{Cu}(\mathrm{II})$ binding at site 1 [105]. In summary, CD and EPR spectroscopy indicate that the $\mathrm{N}$-terminal region of $\mathrm{AS}$ has two independent $\mathrm{Cu}(\mathrm{II})$ binding sites: the first equivalent of $\mathrm{Cu}$ (II) added binds to site 1 and is associated with metal coordination to the free $\alpha-\mathrm{NH}_{2}$ group of Met1 , while a lower affinity event is associated with the binding of a second equivalent of $\mathrm{Cu}$ (II) to His-50 in site 2 (Fig. 5A). Consistently, tryptophan fluorescence studies using AS mutants containing single Trp substitutions or Trp-containing peptides demonstrate that the motif identified as the high affinity N-terminal $\mathrm{Cu}(\mathrm{II})$ binding 


\section{(A)}

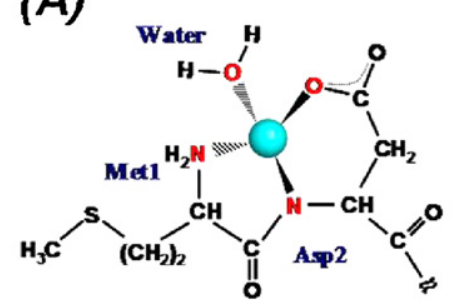

Site 1<smiles>CC1Cc2cncn2[C@H](O)[C@H](C)N1C(=O)N(C)C</smiles>

Site 2

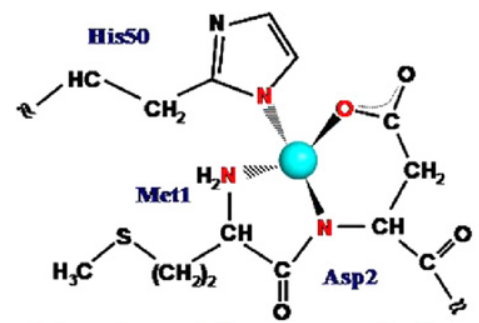

Site 1 and 2 macrochelate<smiles>CC(C)CCC(=O)OC(OC(=O)CC(C)C)(OC(=O)CC(C)C)OC(=O)CC(C)C</smiles>

Site 3

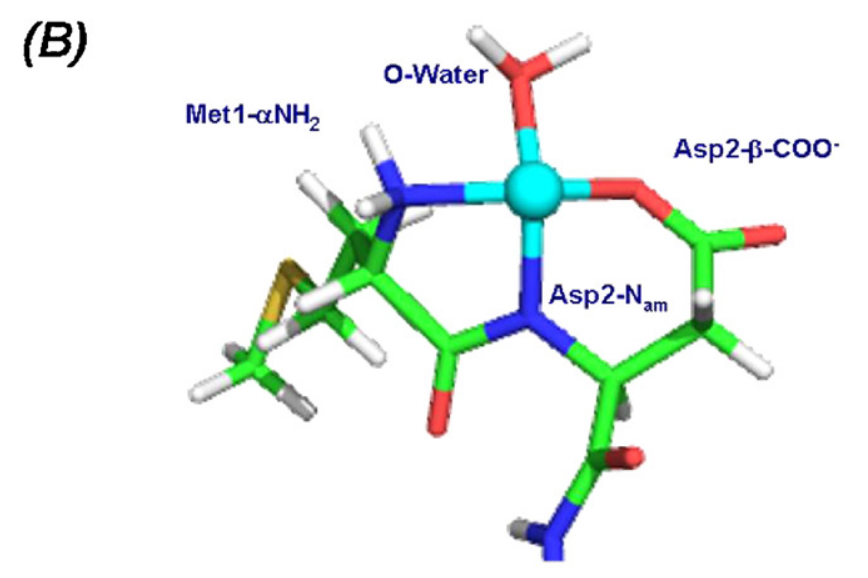

Structure of site 1 AS-CU(II) complex

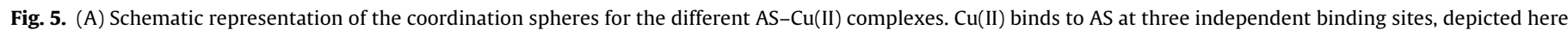

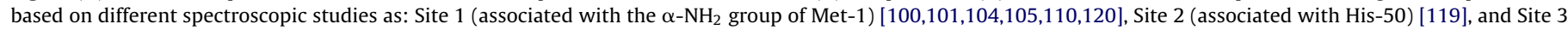

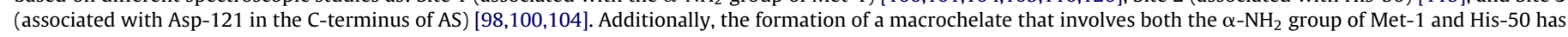
been proposed [112-114]. (B) Structure of site 1 AS-Cu(II) complex as determined by QM/MM simulation on the full length [105].

site does not involve His-50, but includes the first four residues ${ }^{1} \mathrm{MDVF}^{4}$ of the protein primary sequence [101,110,111].

The picture of having two independent $\mathrm{Cu}(\mathrm{II})$ binding sites at the N-terminal of AS has been challenged by recent studies, where electron spin-echo modulation (ESEEM) data suggest the participation of His-50 in the high affinity $\mathrm{Cu}(\mathrm{II})$ binding site [112-114]. ESEEM is a pulsed EPR technique that allows the detection of weak super-hyperfine couplings arising from nuclei approximately $10 \AA$ away from the paramagnetic center. X-band ESEEM spectra of $\mathrm{Cu}(\mathrm{II})$ bound to His residues yield characteristic quadrupolar transitions associated with the coupling with the distal nitrogen of the imidazole group [115]. Three-pulse ESEEM spectra of $\mathrm{AS}-\mathrm{Cu}(\mathrm{II})$ at $\sim 1: 1$ ratio show the characteristic signals associated with $\mathrm{Cu}(\mathrm{II})-\mathrm{His}$ interaction. These results have been interpreted as evidence for the formation of a macrochelate, where $\mathrm{Cu}(\mathrm{II})$ is bound to the imidazole ring of His-50 and to the terminal group $\mathrm{NH}_{2}$ of Met-1 (Fig. 5A). While some authors propose that there may be a dynamic equilibrium between the macrochelate and site
$1 \mathrm{Cu}$ (II)-binding structures (Fig. 5A) [113]; others associate this macrochelate structure to the only high affinity $\mathrm{Cu}(\mathrm{II})$ binding motif in AS [112,114]. The latter conclusion is not compatible with the $\mathrm{CD}$ results discussed above, where clearly two distinct sets of electronic transitions can be identified as they grow sequentially with the first 2 equiv. of $\mathrm{Cu}(\mathrm{II})$ added, whereas the signals associated with the high affinity site in the full protein lack the characteristic LMCT bands of $\mathrm{Cu}(\mathrm{II})-\mathrm{His}$ interactions, strongly arguing against the overall macrochelate hypothesis. Further evidence against the formation of a macrochelate has been provided by two EPR studies $[116,117]$. Alternatively, as ESEEM is such a sensitive technique, those signals may rise from a small amount of $\mathrm{Cu}$ (II) loading into the His-50 site (site 2 ) as site 1 gets saturated. ESEEM experiments at lower metal:protein ratios could shed more light into this point.

Spectroscopic studies using fragments of AS encompassing residues 30-56 leaded by Met and Asp at the N-terminal have proposed that $\mathrm{Cu}(\mathrm{II})$ coordination modes involving the terminal $\mathrm{NH}_{2}$ group and the imidazole ring of His-50 can be formed [118]. 
However, although this may be possible when the terminal $\mathrm{NH}_{2}$ group is placed 20 residues away from the His residue, in the full protein there are 50 residues between the two $\mathrm{Cu}(\mathrm{II})$ anchoring sites, and the entropic penalty in forming such a macrochelate would not be negligible [117]. NMR experiments based on paramagnetic relaxation enhancement (PRE) measurements demonstrated also the lack of any persistent long-range contacts between position 50 and the $\mathrm{N}$-terminus of $\mathrm{AS}$, which might contribute to the stabilization of a macrochelate structure upon $\mathrm{Cu}(\mathrm{II})$ addition [102]. Furthermore, the fact that $\mathrm{CD}$ and EPR spectra of $\mathrm{Cu}$ (II) bound to synthetic peptides encompassing the metal binding regions at the $\mathrm{N}$-terminus of AS, namely ${ }^{1}$ MDVFMK ${ }^{6}$ and ${ }^{45}$ KEGVVHGVATV $^{55}$, are identical to those corresponding to the full length protein, supports the notion of having two independent sites [105,119].

\section{2. $\mathrm{Cu}(\mathrm{II})$ coordination modes at the $\mathrm{N}$-terminal region of $A S$}

Beyond the controversy described above, a lot of consensus can be built on the nature of the $\mathrm{Cu}(\mathrm{II})$ coordination modes at the $\mathrm{N}$-terminal region of AS. There is wide agreement in that the amino terminal group of Met- 1 is associated with the highest affinity binding site for $\mathrm{Cu}(\mathrm{II})$. Most authors identify this group as an equatorial ligand [104,105,113,114,117], while there is one proposal for it to be coordinated axially [112]. The EPR signals associated with this site are characteristic of type- $2 \mathrm{Cu}(\mathrm{II})$ proteins; while their $g_{\|}=2.250$ and $A_{\|}=189 \times 10^{-4} \mathrm{~cm}^{-1}$ indicate a $2 \mathrm{~N} 2 \mathrm{O}$ coordination mode. The LMCT band at $300 \mathrm{~nm}$ identified by absorption and CD spectroscopy is characteristic of amide bonding to $\mathrm{Cu}(\mathrm{II})$ and it has been associated with the amide backbone of Asp-2 [104,105,112-114,118,120]. This assignment is based on several studies on model peptides with aspartyl residues in position 2 , where the formation of highly stable $\mathrm{Cu}(\mathrm{II})$ complexes arise through direct metal coordination to the amino group of residue 1 , and deprotonated amide nitrogen and carboxylate side-chains of residue at position 2 [121]. Coordination of $\mathrm{Cu}$ (II) to the amino terminal group of Met- 1 favors deprotonation of the amide nitrogen of Asp-2. Thus, the two nitrogen ligands for $\mathrm{Cu}(\mathrm{II})$ at site 1 are the amino terminal group of Met-1 and the amide backbone of Asp-2 (Fig. 5A).

The role of the $\beta-\mathrm{COO}^{-}$group of Asp- 2 as an oxygen-based ligand for $\mathrm{Cu}(\mathrm{II})$ has been investigated by $\mathrm{CD}$, EPR and isothermal titration calorimetry (ITC). The D2A substitution in AS and ${ }^{1}$ MDVFMK ${ }^{6}$ AS peptide fragments yielded drastic changes in the $C D$ and EPR spectra of their corresponding $\mathrm{Cu}$ (II) complexes, reflecting a different coordination environment for the metal ion [105,114]. The unique involvement of Met- 1 and Asp- 2 in $\mathrm{Cu}(\mathrm{II})$ coordination to ${ }^{1}$ MDVFMK ${ }^{6}$ peptide and the role of the carboxylate side chain of Asp-2 as metal anchoring group was strongly supported by NMR [105]. Moreover, ITC experiments on the D2A variant of this binding site $\left({ }^{1}\right.$ MAVFMK ${ }^{6}$ sequence) confirmed a significantly decreased binding affinity for $\mathrm{Cu}(\mathrm{II})$, demonstrating that Asp-2 plays a key role in high affinity $\mathrm{Cu}(\mathrm{II})$ coordination to site 1 [105]. In fact, the enhanced stability of the $\left(\alpha \mathrm{NH}_{2}, \mathrm{~N}^{-}, \beta-\mathrm{COO}^{-}\right)-\mathrm{Cu}(\mathrm{II})$ coordination environment has been attributed to the presence of an extra negative charge and the formation of $(5,6)$-member joined chelate rings $[121,122]$. Asp-2 plays a dual role in $\mathrm{Cu}(\mathrm{II})$ coordination at this site: it binds directly to the metal ion, and it substantially increases the acidity of the backbone amide group. An interesting comparison of the role of Asp-2 in AS can be made to that of Asp-1 in $\mathrm{Cu}(\mathrm{II})$ binding to $A \beta$, where the carboxylate residue stabilizes the protonated form of the backbone amide through a hydrogen bonding interaction $[123,124]$.

Finally, the identification of the other oxygen-based ligand as a water molecule has derived from the EPR signal broadening observed upon ${ }^{17} \mathrm{O}$ enrichment of the $\mathrm{Cu}(\mathrm{II})$ complex with the ${ }^{1}$ MDVFMK $^{6}$ peptide. Simulations of this broadening effect, considering one equatorial oxygen coordinated to the metal ion, led to a super-hyperfine coupling constant for ${ }^{17} \mathrm{O}$ of $13 \times 10^{-4} \mathrm{~cm}^{-1}$; which is consistent with the presence of one water molecule coordinated to $\mathrm{Cu}(\mathrm{II})$ in an equatorial position [105]. Supporting this assignment, ${ }^{1} \mathrm{H}$ pulsed electron nuclear double resonance (ENDOR) and HYSCORE studies on a 1-99 AS fragment with 0.9 equiv. of $\mathrm{Cu}$ (II) added identified the presence of two weakly coupled protons; while two pulse ESEEM spectra on the same sample yielded the characteristic modulation associated with the presence of equatorial water molecules [112].

In summary, the high affinity $\mathrm{Cu}$ (II) binding site in AS (or site 1) encompasses a $2 \mathrm{~N} 2 \mathrm{O}$ ligand donor set, composed by the $\alpha-\mathrm{NH}_{2}$ group of Met-1, the deprotonated amide nitrogen and $\beta-\mathrm{COO}^{-}$of Asp-2, and a water molecule (Fig. 5A). The structural parameters are characteristic of a $\mathrm{Cu}$ (II) coordination in a type II distorted tetragonal arrangement. A structural model reported for the high-affinity AS- $\mathrm{Cu}$ (II) complex, as built by QM/MM molecular dynamics (MD), further support this conclusion (Fig. 5B) [105].

In contrast, the study of $\mathrm{Cu}(\mathrm{II})$ coordination to the imidazol ring of His-50 has advanced to a less extent, and it has been obscured by the controversy mentioned above. EPR parameters associated with a $\mathrm{Cu}(\mathrm{II})-\mathrm{His}-50$ complex (or site 2 ), $g_{\|}=2.228$ and $A_{\|}=179 \times 10^{-4} \mathrm{~cm}^{-1}$, indicate that a ligand set of $1 \mathrm{~N} 3 \mathrm{O}, 2 \mathrm{~N} 2 \mathrm{O}$ or 3N10 might be implicated [104,113,119], where His-50 provides one of the nitrogen ligands. Based on spectroscopic studies on the full protein and the synthetic AS peptide ${ }^{45} \mathrm{KEGVVHGVATV}^{55}$ a coordination mode where two more nitrogen ligands are provided by deprotonated amides of His-50 and Val-49 has been proposed (Fig. 5A) $[113,119]$. It has also been anticipated that a water molecule may provide an oxygen ligand, although no experimental evidence for such a scenario is available. Alternatively, an oxygen ligand may be provided by a backbone carbonyl group, as found in other His-anchored $\mathrm{Cu}(\mathrm{II})$ binding sites, such as the His96 site in the prion protein [125]. Finally, the role of Glu-46 in $\mathrm{Cu}(\mathrm{II})$ binding at this site has been evaluated in the ${ }^{45}$ KEGVVHGVATV $^{55}$ model peptide and the full protein; however, no substantial differences were observed upon the pathogenic E46K substitution that is found in patients of genetically linked PD [117,119].

\section{3. $\mathrm{Cu}(\mathrm{II})$ coordination to the C-terminal region of AS}

The lowest affinity binding interface identified at the Cterminus of AS involves multiple $\mathrm{Cu}(\mathrm{II})$ binding sites, as revealed by NMR spectroscopy $[98,100]$. The affected region comprises residues $110-140$, which also constitute the primary binding site for the polycationic polyamines [23]. However, as demonstrated upon knock out of the N-terminal $\mathrm{Cu}(\mathrm{II})$ binding sites by DEPC modification or protonation of His-50, AS- $\mathrm{Cu}$ (II) interactions within this interface is initially highly localized around residues ${ }^{119}{ }^{D P D N E A}{ }^{124}$, which constitute the primary site for metal coordination at the C-terminal region. Additionally, NMR data indicate that metal binding to this region is not driven exclusively by electrostatic interactions, but it is mostly determined by the residual structure of the C-terminus of AS [98]. EPR spectroscopy indicates that the $\mathrm{Cu}(\mathrm{II})$ atom bound to this site has four oxygen donors, suggesting the involvement of carboxylates as major contributors to metal binding [100,104,113]. Residues Asp-119, Asp-121, Asn-122, and Glu-123 likely represent the ligand set for the metal ion (or site $3)$, as shown in Fig. 5A.

\section{Affinity features of $\mathrm{Cu}(\mathrm{II})$ binding to AS}

The metal binding affinity of proteins and peptides is an important parameter in biology. It gives information about the physiological significance of the interaction of a protein/peptide 
Table 1

Affinity features reported for AS-Cu(II) complexes.

\begin{tabular}{|c|c|c|c|c|}
\hline Affinity range, $K_{d}(\mathrm{M})$ & Binding features & Technique & Experimental conditions & Ref. number \\
\hline $10^{-5}$ & Site 3 & Equilibrium centrifugation & MES buffer, $\mathrm{pH} 6.5,37^{\circ} \mathrm{C}$ & [97] \\
\hline $10^{-7}\left(10^{-9}\right)$ & Site 1 & UV-vis, CD, NMR, ITC & MES, MOPS or Hepes buffer, pH 6.5-7.5, $\mathrm{NaCl} 100 \mathrm{mM}, 15^{\circ} \mathrm{C}$ & \\
\hline $10^{-5}\left(10^{-6}\right)$ & Site 2 & & & {$[98,100,104,105]$} \\
\hline $10^{-3}$ & Site 3 & & & \\
\hline $10^{-7}\left(10^{-9}\right)$ & Site 1 & Fluorescence & MOPS buffer, pH 7.0, $\mathrm{NaCl} 100 \mathrm{mM}, 25^{\circ} \mathrm{C}$ & {$[101,110]$} \\
\hline $10^{-10}$ & n.r. & ITC & PIPES buffer, pH 7.4, $\mathrm{NaCl} 103 \mathrm{mM}, 1: 4 \mathrm{Cu}$ (II):Gly ratio, $37^{\circ} \mathrm{C}$ & {$[128,129]$} \\
\hline $10^{-10}$ & n.r. & ITC & MOPS buffer, pH 7.0, $1: 4 \mathrm{Cu}(\mathrm{II})$ :Gly ratio, $25^{\circ} \mathrm{C}$ & {$[134]$} \\
\hline $10^{-8}$ & n.r. & & & \\
\hline $10^{-10}$ & Macrochelate ${ }^{b}$ & EPR & MOPS buffer, pH 7.4 & {$[114]$} \\
\hline $10^{-5}$ & n.r. & & & \\
\hline
\end{tabular}

The $\mathrm{Cu}(\mathrm{II})$ binding modes classified as sites 1-3 and macrochelate correspond to the coordination environments shown in Fig. 5A.

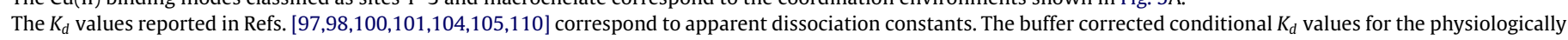
relevant high affinity AS-Cu(II) complex is reported in brackets.

The $K_{d}$ values reported in Refs. $[114,128,129,134]$ correspond to conditional dissociation constants. n.r.: not reported.

with a given metal ion. Particularly, in the frame of discussion relevant for this work, an important question to address is whether the interaction of $\mathrm{Cu}(\mathrm{II})$ with AS occurs in vivo. In that direction, several studies have shown that both AS and copper are highly abundant in brain tissue. Indeed, AS accounts for approximately $1 \%$ of the total protein content in the striatum [126] and copper concentration in brain tissue is in the micromolar range [127]. Even if these evidences allow us to speculate that $\mathrm{Cu}(\mathrm{II})$ binding to AS might be physiologically relevant, a binding affinity that is too low may indicate that the protein is not able to bind the metal ion in vivo.

To shed light on the affinity features of the AS-Cu(II) complexes several studies have been carried out in recent years. The values of experimental dissociation constants reported in the literature vary considerably, depending on the technique applied to determine these values, the experimental and solution conditions, and the different ways to extract the binding constants from the data (Table 1).

Initial studies using equilibrium centrifugation techniques showed that AS is able to bind five or more copper ions with a $K_{d}$ of 4-6 $\times 10^{-5} \mathrm{M}$ [97]. Although the AS-Cu(II) complexes were not characterized structurally, $\mathrm{Cu}$ (II) was claimed to bind exclusively to the negatively charged C-terminal region. However, a more recent analysis using a battery of low and high-resolution spectroscopic techniques revealed that the protein tightly binds only two copper ions per monomer with dissociation constants in the $10^{-7}$ to $10^{-5} \mathrm{M}$ range $[98,100,104]$. To discourage protein aggregation, the studies described above were performed using recombinant proteins of very high purity in the $\mathrm{pH}$ range $6.5-7.5$ and at $15^{\circ} \mathrm{C}$.

Through the design of site-directed and domain-truncated mutants of AS the high and low affinity constants were unequivocally assigned to specific copper-binding motifs located in the $\mathrm{N}$-terminal region, described in the previous section as $\mathrm{Cu}(\mathrm{II})$ sites 1 and 2 [104]. Instead, $\mathrm{Cu}$ (II) binding to the $\mathrm{C}$-terminal region of synucleins was confirmed to represent a non-specific, very low affinity process characterized by dissociation constants in the $\mathrm{mM}$ range $\left(K_{d} \sim 1-2 \times 10^{-3} \mathrm{M}\right)$. These observations imply that $\mathrm{Cu}(\mathrm{II})$ binding to the N-terminus of AS might occur under physiologically relevant conditions, and thus, it might be biologically relevant to the etiology of PD. In contrast, the weak C-terminal binding has little chance to occur in the presence of a pool of various proteins and amino acids in vivo. We will therefore focus the discussion mainly on the strong binding of $\mathrm{Cu}(\mathrm{II})$ to the $\mathrm{N}$-terminal region of the protein.

Through the use of isothermal titration calorimetric (ITC) measurements more reliable values were obtained for the affinity of the first and second equivalent of $\mathrm{Cu}(\mathrm{II})$ bound to the $\mathrm{N}$-terminal region of AS $\left(K_{d 1}=1.0 \pm 0.1 \times 10^{-7} \mathrm{M}\right.$ for site 1 and $K_{d 2}=3.5 \pm 0.4 \times 10^{-5} \mathrm{M}$ for site 2) [105]. The dissociation constants of the $\mathrm{Cu}(\mathrm{II})$ complexes were estimated from studies performed on wt AS, its mutant H50A, the C-terminal truncated variants 1-108 AS, H50A 1-108 AS, and a synthetic peptide containing the sequence ${ }^{1}$ MDVFMK $^{6}[104,105]$. The results derived from these studies demonstrate conclusively that His-50 is not required to determine the high affinity features of $\mathrm{Cu}(\mathrm{II})$ binding site 1 and confirms that transient long-range interactions between the $\mathrm{N}$ - and $\mathrm{C}$-terminal regions of AS do not influence the binding preferences or the affinity of $\mathrm{Cu}(\mathrm{II})$ at each site.

Copper binding to AS was also assessed by tryptophan fluorescence measurements in AS mutants containing single W substitutions (F4W, Y39W, F94W, Y125W and F4W/H50S), taking advantage of the fact that $\mathrm{Cu}(\mathrm{II})$ binding would quench tryptophan fluorescence site-specifically [101]. These studies were performed on submicromolar protein concentrations $(100 \mathrm{nM})$, allowing the authors to extract very reliable values of dissociation constants. The estimated dissociation constant was $K_{d 1} \sim 1.0 \times 10^{-7} \mathrm{M}$, consistent with the measurements by Fernández and co-workers. The similarity in binding constants for the F4W and $\mathrm{F} 4 \mathrm{~W} / \mathrm{H} 50$ S proteins, and the fact that the first four residues ${ }^{1} \mathrm{MDVF}^{4}$ preserved $\mathrm{Cu}$ (II) affinity $\left(K_{d 1}=2.0 \pm 0.2 \times 10^{-7} \mathrm{M}\right)[110]$, further confirm that these high affinity features correspond to $\mathrm{Cu}(\mathrm{II})$ binding to site 1 and that this site does not involve the His-50 imidazole group.

Evaluation of $\mathrm{Cu}(\mathrm{II})$ binding to A30P, A53T and wild type AS by another group concluded that the binding constants for $\mathrm{Cu}(\mathrm{II})$ to the three AS proteins are similar, with values in the low nanomolar range $\left(10^{-10} \mathrm{M}\right)[128,129]$. A second binding site with a larger binding constant is reported only for the A30P variant, which is attributed to the binding of $\mathrm{Cu}(\mathrm{II})$ to small oligomeric species of $\mathrm{AS}$ [128]. It is important to note that the binding constants reported by Hong and Simon in those studies $[128,129]$ were obtained using an excess of glycine to stabilize $\mathrm{Cu}(\mathrm{II})$, and their values are higher than those determined with $\mathrm{Cu}(\mathrm{II})$ in aqueous buffer $[101,104,105,110]$. The authors suggested that the weak $\mathrm{Cu}(\mathrm{II})$ binding to the $\mathrm{C}$ terminus of AS might contribute to the smaller affinities reported in the studies by Fernández and Lee but these arguments were not supported by further experiments. Indeed, the $\mathrm{Cu}(\mathrm{II})$ affinity features reported previously are the result of an exhaustive analysis performed on several AS variants, including C-terminal truncated 1-108 AS and H50A 1-108 AS, which were designed precisely to lack the weak $\mathrm{Cu}(\mathrm{II})$ binding component at the C-terminus of AS $[101,104]$. Moreover, the dissociation constants reported for the high affinity site in full length and C-terminal truncated AS are preserved in the ${ }^{1}$ MDVFMK ${ }^{6}$ and ${ }^{1}$ MDVF $^{4}$ peptides $[105,110]$.

However, the discrepancies of the affinity features reported by Fernández and Lee with those of Simon can be reconciled by taking 
into account the interaction of AS with buffers. Indeed, the dissociation constants determined by Fernández and Lee are apparent dissociation constants (i.e. in the presence of buffer), while those reported by the group of Simon are conditional dissociation constants (at a given $\mathrm{pH}$, temperature), where competition with buffer may be neglected due to complexation of the metal ion with Gly. The apparent $K_{d}$ values from Fernández and Lee can be converted to conditional $K_{d}$ values by taking into account the competition with buffers [54,130,131], resulting in values of dissociation constants in the $1-5 \times 10^{-9} \mathrm{M}$ range, closer to the values reported by Simon $\left(K_{d} \sim 10^{-10} \mathrm{M}\right)$.

Even though this explanation accounts for most of the discrepancy between the values found by Fernández and Lee and those determined by Simon, there may be other factors to consider. It is worth noting that the purity and aggregation level of the protein samples might also affect affinity measurements. The high temperatures $\left(37^{\circ} \mathrm{C}\right)$ used in the calorimetric experiments reported by Hong and Simon $[128,129]$ are known to be a potent inductor of AS aggregation, an effect that is dramatically enhanced when working with $\mathrm{Cu}(\mathrm{II})$-loaded samples and AS variants such as A30P and A53T, that exhibit a notably increased rate of oligomerization compared to the wild type species [132]. Indeed, the larger binding constant reported for the A30P form was attributed by Simon and co-workers to the binding of $\mathrm{Cu}$ (II) to small oligomeric species that were present in solution in slow equilibrium with the monomeric protein.

Adding controversy to the binding preferences of $\mathrm{Cu}(\mathrm{II})$ on AS, another ITC-based work performed on six synthetic 25-amino acid fragments has disputed the involvement of the $\mathrm{N}$-terminus of AS as the preferential binding interface for $\mathrm{Cu}$ (II) ions. According to this work, only peptides corresponding to sequences 46-70 and $116-140$ bind $\mathrm{Cu}(\mathrm{II})$ with measurable affinity $\left(\sim 10^{-5} \mathrm{M}\right)$ [133]. However, a more recent calorimetric study from the same research group states that wild type recombinant AS binds a single equivalent of $\mathrm{Cu}(\mathrm{II})$ in two thermodynamically distinct binding modes at the $\mathrm{N}$-terminal region of $\mathrm{AS}$, with conditional dissociation constants of $\sim 4.0 \times 10^{-10} \mathrm{M}$ and $\sim 6.0 \times 10^{-8} \mathrm{M}$ [134].

Finally, an EPR study using high-affinity competitors also showed that monomeric AS binds 1.0 equiv. of $\mathrm{Cu}$ (II) with a conditional $K_{d}$ of $\sim 1.0 \times 10^{-10} \mathrm{M}$, although a second lower-affinity species $\left(\sim 10^{-5} \mathrm{M}\right)$ is detected beyond 1 equiv. of $\mathrm{Cu}$ (II) added [114]. In this work, the high affinity binding mode has been assigned the formation of a macrochelate, where $\mathrm{Cu}(\mathrm{II})$ is bound to the terminal $\mathrm{NH}_{2}$ of Met-1 group and the imidazole ring of His-50.

Overall, the evidences discussed here indicate that $\mathrm{Cu}(\mathrm{II})$ has unique binding modes and affinity features compared to other transition metal ions. These properties will be discussed later in the context of the structural and molecular basis behind the mechanism of copper mediated AS aggregation enhancement and its biological significance.

\section{Mechanistic basis behind the copper-mediated AS amyloid assembly}

The results described in previous sections provide compelling evidence for a low affinity metal binding interface at the C-terminus of AS, while AS binds $\mathrm{Cu}(\mathrm{II})$ with high affinity at two binding sites in the N-terminal region. These key differences in the affinity features are clearly dictated by structural factors corresponding to different protein regions, and they reveal a strong link between the specificity of metal binding to AS and their effectiveness in accelerating AS aggregation. The connection of such structural-affinity differences with the mechanistic basis behind the metal induced AS fibrillation process is discussed in this section.

\subsection{Non-specific, C-terminus mediated mechanism}

It is well documented that AS binds metal ions to the C-terminus with very low selectivity. A coordination site formed mostly by carboxylate side-chains is in agreement with the modest affinity constants $\left(10^{-3} \mathrm{M}\right.$ range) observed for the binding of $\mathrm{Cu}$ (II) and other divalent metal ions to the C-terminus of the protein. This is also in agreement with the high concentrations of metal ions required to induce the aggregation of AS through this nonspecific mechanism. The existence of multiple metal binding sites at the C-terminus might be likely involved in the aggregation pathway by forming transient intermediate species (e.g. dimers), where the metal ions would serve to bridge multiple interfaces. Indeed, these interactions would be significantly stabilized only at high metal:protein ratios, such as those necessary to induce the aggregation of AS [84,98]. It has also been proposed that the binding of millimolar concentrations of metal ions to the negatively charged C-terminal region of AS might lead to masking of the electrostatic repulsion and the collapse to a partially folded conformation [84]. The formation of a partially folded intermediate, which would be more prone to aggregate than the intrinsically disordered monomeric state of the protein has also been suggested to occur under conditions of low $\mathrm{pH}$ and elevated temperatures [135]. However, in contrast with CD and ANS binding experiments [84,135], the invariance of NMR parameters such as the chemical shifts of backbone amide resonances and the hydrodynamic radius of the protein indicate that there is no substantial conformational changes, nor the induction of a partially misfolded species even in the presence of millimolar levels of metal ions [98]. Despite these discrepancies, the established structural-affinity relationship supports a mechanism of metal-induced AS aggregation sharing common features for $\mathrm{Cu}(\mathrm{II})$ and other divalent ions when the protein is exposed to levels of metal ions in the millimolar range (Fig. 6A), and it indicates that this process differs significantly from that induced by the specific binding of $\mathrm{Cu}(\mathrm{II})$ to the N-terminal region of AS.

\subsection{Specific, $N$-terminus mediated mechanism}

In order to address the role of $\mathrm{Cu}$ (II) binding sites at the $\mathrm{N}$ terminal on the metal-mediated AS aggregation, the effect of low micromolar $\mathrm{Cu}(\mathrm{II})$ concentrations on the aggregation rate of $\mathrm{H} 50 \mathrm{~A}$ AS and the C-terminal truncated variants 1-108 AS and H50A 1-108 AS was first assessed. These variants represented a useful model system to understand the mechanism by which copper induces AS aggregation, in particular, whether specific binding of $\mathrm{Cu}(\mathrm{II})$ to site 1 is sufficient to trigger amyloid formation. These studies demonstrated conclusively that the acceleration of AS aggregation induced by $\mathrm{Cu}(\mathrm{II})$ is driven by its specific binding to site 1 , whereas the formation of the AS-Cu(II) complex at site 1 constitutes the critical step in copper-mediated AS aggregation [105].

In terms of the structural and mechanistic basis behind coppermediated AS aggregation, these results indicate that the effect of low micromolar $\mathrm{Cu}(\mathrm{II})$ concentrations on AS aggregation in vitro, at least at the earliest aggregational events, is not related to specific His binding, nor to the interaction with clusters of negatively charged residues at the $\mathrm{C}$-terminal region. This notion is further supported by the absence of any interplay or modulation among the identified $\mathrm{Cu}$ (II) binding sites on the wt species [101,102,104]. In contrast to the observations for $A \beta$ peptide and prion protein, where aggregation is affected by the formation of $\mathrm{His}-\mathrm{Cu}$ (II) complexes [51,53,54,65,68,72-74,136-139], the presence of His-50 in AS does not influence the aggregation process triggered by copper binding at the $\mathrm{N}$-terminal region, arguing against an active role for this residue in the structural and biological events involved in the mechanism of copper-mediated AS aggregation. The presence 
(A)

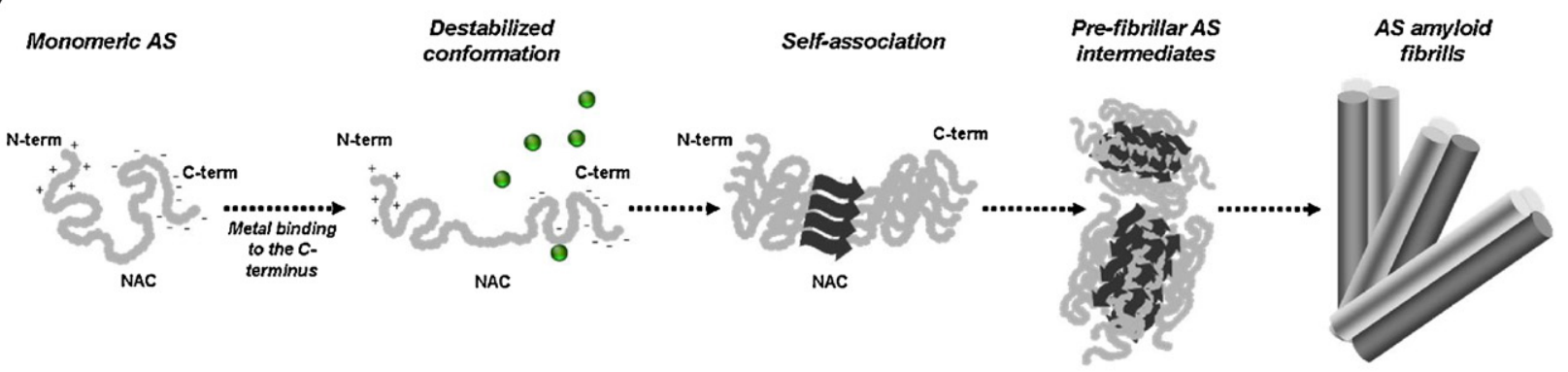

(B)

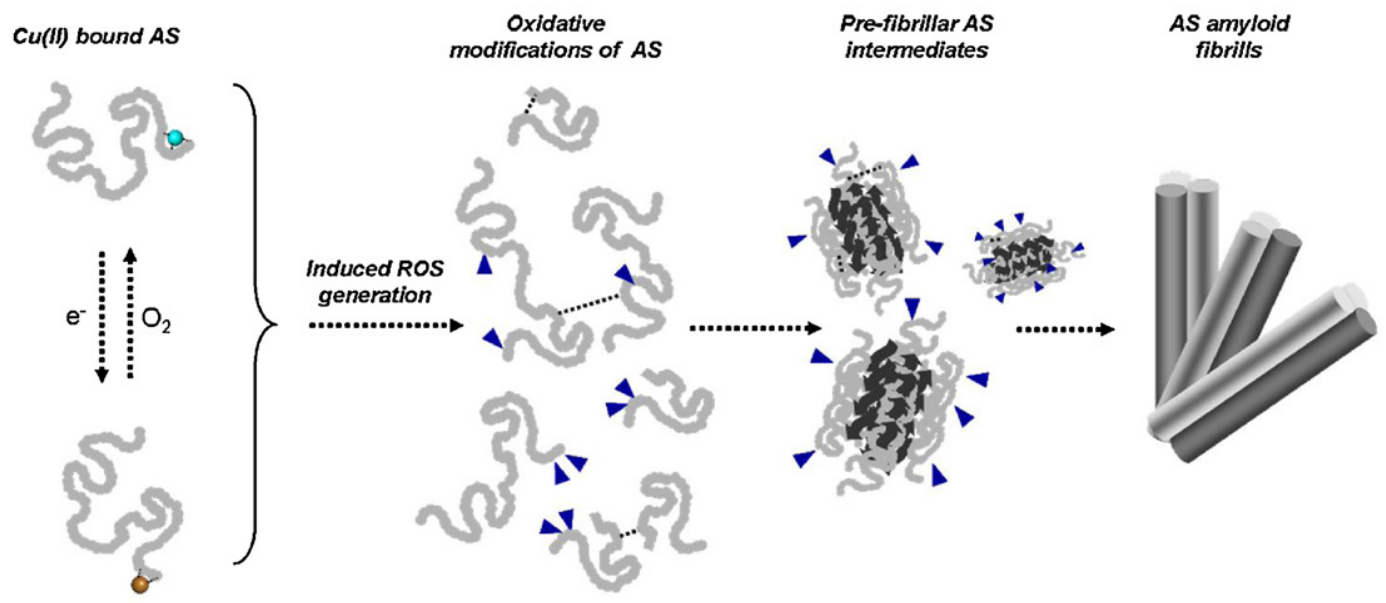

Cu(i) bound AS

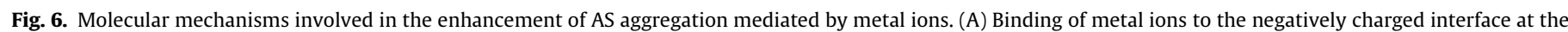

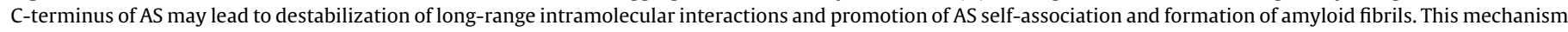

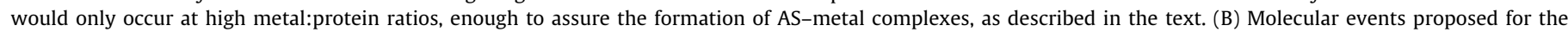

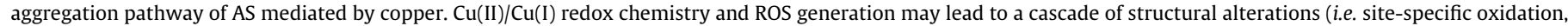

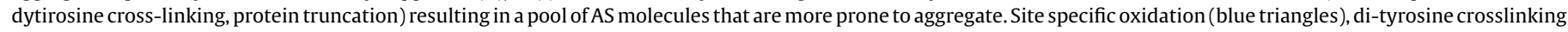
(dotted line) and fragmentation of AS mediated by AS-Cu interactions are well documented in literature [148,149,151,152].

of several copper-coordinating His residues in the $A \beta$ and prion sequences, compared with the sole His-50 in AS, seems to be a key difference that influences significantly the mechanism of aggregation mediated by $\mathrm{Cu}(\mathrm{II})$ in these proteins.

Elucidation of the residue-specific effects mentioned above is a key step for understanding the mechanism of copper-induced fibrillogenesis of AS. Comparable to $A \beta$ peptide and prion protein, AS is also highly susceptible to metal catalyzed oxidation, a reaction that induces extensive oligomerization and precipitation of these proteins [89-92,140-144]. The $\mathrm{Cu}(\mathrm{II})$ catalyzed oxidation of AS has been subject of numerous studies that aim to establish a link between protein aggregation and oxidative damage. Co-incubation of the protein with $\mathrm{Cu}$ (II) and $\mathrm{H}_{2} \mathrm{O}_{2}$ led to the formation of amyloid fibrils [140], whereas $\mathrm{H}_{2} \mathrm{O}_{2}$ treated AS did not form amyloid fibrils but it generated soluble non-toxic oligomers. These results further underscore the catalytic role of copper chemistry in the amyloid assembly of AS [145,146].

\subsection{The role of copper catalyzed oxidation}

The $\mathrm{Cu}(\mathrm{II})$ catalyzed oxidation reaction involves the reduction of $\mathrm{Cu}(\mathrm{II})$ by a suitable electron donor and the conversion of molecular oxygen into reactive oxygen species (ROS), which trigger the oxidative modification of the protein. For AS-Cu(II) complexes, this implies that the metal ion has to be first reduced at the protein site by electron donors such as NADH, NADPH, ascorbate, gluthatione or the protein itself. Then, the reduced metal ion bound to specific metal-binding sites catalyzes the reduction of molecular oxygen to generate $\mathrm{H}_{2} \mathrm{O}_{2}$ and $\mathrm{OH}^{\bullet}$ (Eqs. (1)-(4)), which in turn oxidize neighboring amino acid residues, resulting in protein damage [147].

$$
\begin{aligned}
& \text { AS-metal }{ }^{\mathrm{ox}}+\mathrm{e}^{-} \rightarrow \text { AS-metal } \\
& \text { AS-metal } \\
& \text { red }+\mathrm{O}_{2} \rightarrow \text { AS-metal } \\
& \text { AS-metal }{ }^{\text {red }}+\mathrm{O}_{2}{ }^{\bullet-}+2 \mathrm{H}^{+} \rightarrow \text { AS-metal } \\
& \text { ox }+\mathrm{H}_{2} \mathrm{O}_{2} \\
& \text { AS-metal }
\end{aligned}
$$

These reactions set up a catalytic cycle where the AS-metal ${ }^{\text {ox }}$ complex acts like a catalyst to continuously facilitate the reduction of $\mathrm{O}_{2}$ to $\mathrm{H}_{2} \mathrm{O}_{2}$, leading to the depletion of cellular reductants.

The described mechanism is a highly selective, site-specific process that involves interactions of the protein with both oxidation states of the copper ion. Indeed, the occurrence of an associated $\mathrm{Cu}(\mathrm{I}) /$ dioxygen chemistry and a detailed description of the structural and binding features of $\mathrm{Cu}(\mathrm{I})$ to AS have been reported recently and are discussed in the next section $[148,149]$. Moreover, cyclic voltammetry data shows that the high affinity AS- $\mathrm{Cu}(\mathrm{II})$ complex at the $\mathrm{N}$-terminus can be reduced and the resulting $\mathrm{AS}-\mathrm{Cu}(\mathrm{I})$ complex can undergo further re-oxidation with generation of $\mathrm{H}_{2} \mathrm{O}_{2}$ and other ROS that are toxic to dopaminergic cultured cells [150]. Based on the reduction potential of the AS-Cu(II) complex $(0.018 \mathrm{~V}$ vs $\mathrm{Ag} / \mathrm{AgCl})$, different highly abundant cellular reductants, such as ascorbate, could serve as efficient electron reservoirs for the reaction to occur. It has also been proposed that, even though the AS- $\mathrm{Cu}(\mathrm{II}) / \mathrm{Cu}(\mathrm{I})$ pair cannot directly oxidize dopamine, the $\mathrm{H}_{2} \mathrm{O}_{2}$ 
produced under reducing conditions can certainly do, suggesting also a potential role of AS-copper interactions in perturbing the normal dopamine metabolism [150].

A wide range of structural modifications, involving oxidation of amino acid residue side chains, formation of protein-protein cross-linkages, oxidation of the protein backbone and protein fragmentation have also been reported for peptides containing $\mathrm{Cu}$ (II) coordinated to the high-affinity site, as they were treated with $\mathrm{H}_{2} \mathrm{O}_{2}$ or co-incubated with ascorbate under aerobic conditions $[149,151,152]$. Furthermore, it was shown that upon $\mathrm{Cu}(\mathrm{II})$ coordination to $\mathrm{AS}$, metal reduction from $\mathrm{Cu}(\mathrm{II})$ to $\mathrm{Cu}(\mathrm{I})$ may occur in the absence of dioxygen; whereas in the presence of $\mathrm{O}_{2}$ reoxidation of $\mathrm{Cu}(\mathrm{I})$ to $\mathrm{Cu}(\mathrm{II})$ takes place through the generation of ROS and results in di-tyrosine cross-linking [148]. Di-tyrosine formation has been previously found under extreme neuronal oxidative-stress conditions [153-155], while the study reported here show that these modifications occurs in vitro in the presence of $\mathrm{O}_{2}$ and are greatly enhanced by coordinated copper. Another proposal for an $\mathrm{O}_{2}$ mediated mechanism that connects copper binding with ROS formation and AS aggregation involves the generation of intermolecular peroxobridges between metal centers located in different protein molecules. These early aggregation species would then act as a seed to accelerate AS amyloid assembly [91].

Altogether, as discussed here, several pieces of evidence indicate that in vivo $\mathrm{Cu}(\mathrm{II}) / \mathrm{Cu}(\mathrm{I})$ redox chemistry might be a key event in the pathophysiology of PD. It has also been suggested that copper-induced ROS generation mediates $A \beta$ aggregation. Oxidative modification of $A \beta$ increases its propensity to aggregate, which in turn is proposed to induce $A \beta$ oligomer formation and toxicity in AD [141-143,156-158]. As mentioned previously, reoxidation of the AS- $\mathrm{Cu}(\mathrm{I})$ complex by $\mathrm{O}_{2}$ inflicts toxicity and neuronal cell death [150]. At this point, one can then hypothesize that copper binding to the N-terminus of AS might render the protein a relatively easy target for oxidative damage, which in turn may lead to a cascade of structural alterations (e.g. site-specific oxidation, di-tyrosine crosslinking) that make AS more prone to aggregate (Fig. 6B).

\section{Structural details of $\mathrm{Cu}(\mathrm{I})$ coordination to AS}

As mentioned in the previous section, $\mathrm{Cu}(\mathrm{II}) / \mathrm{Cu}(\mathrm{I})$ redox cycle and the formation of ROS catalyzed by metal amyloid complexes may be a key event in neurodegeneration. However, most of the studies on the interaction of copper with amyloid proteins, including $A S$ and $A \beta$ peptide, have been aimed at elucidating the coordination environment of $\mathrm{Cu}(\mathrm{II})$ bound to the protein. And, although some work has focused on the ROS reactions catalyzed by the copper complexes, information regarding the structure, affinity and reactivity of the protein- $\mathrm{Cu}(\mathrm{I})$ complexes is scarce. Only recently it was shown that the monomeric soluble form of the amyloidogenic $A \beta$ peptide binds $\mathrm{Cu}(\mathrm{I})$ in a linear bis-His geometry that is kinetically slow to react with oxygen to form ROS [68,159-161]. While the affinities of monomeric $A \beta$ for $\mathrm{Cu}(\mathrm{II})$ range widely in the literature $\left(10^{-11}-10^{-9} \mathrm{M}\right)$ [54], the dissociation constant reported by the group of Szalai for the $A \beta-C u(I)$ complex is in the femtomolar range [162]. Thus, it has been speculated that $A \beta-C u(I)$ might be the dominant species in vivo, as part of a neuroprotective mechanism for the adduct formed between the amyloid peptide and the metal ion $[160,162]$. However, reevaluation of $\mathrm{Cu}(\mathrm{I})$ affinity for amyloid $\mathrm{A} \beta$ peptide by a new competition assay has challenged this view, indicating that the dissociation constant for the $\mathrm{A} \beta-\mathrm{Cu}(\mathrm{I})$ complex would be in the submicromolar range [163].

Such important and unresolved issues of the bioinorganic chemistry of neurodegenerative diseases need to be addressed. For PD, two recent studies have shed some light into these questions. The occurrence of an associated $\mathrm{Cu}(\mathrm{I})$ /dioxygen chemistry during
AS fibril formation became evident from extended X-ray absorption fine structure (EXAFS) analysis of soluble and aged AS-copper complexes. These studies showed that AS partially reduces ( 20\%) $\mathrm{Cu}$ (II) ions bound to the high affinity site in an anaerobic environment [148]. Reduction of $\mathrm{Cu}$ (II) to $\mathrm{Cu}$ (I) by AS and the formation of a AS- $\mathrm{Cu}(\mathrm{I})$ complex was indicated by the appearance of a characteristic pre-edge $\mathrm{Cu}(\mathrm{I})$ absorption feature in the X-ray absorption near edge structure (XANES) spectrum of $\mathrm{Cu}$ (II) loaded AS samples upon fibril formation. Since the primary $\mathrm{Cu}$ (II) binding motif of AS at the N-terminus contains two nearby Met residues $\left({ }^{1} \mathrm{MDVFM}^{5}\right)$, the autoreduction of $\mathrm{Cu}$ (II) to $\mathrm{Cu}(\mathrm{I})$ was proposed to be mediated by an electron transfer pathway initiated by Met oxidation. Furthermore, while the monomeric AS- $\mathrm{Cu}(\mathrm{I})$ complex is a stable unreactive form of the copper-protein interaction process under anaerobic conditions; in the presence of $\mathrm{O}_{2}$, the generation of ROS and di-tyrosine cross-linking is greatly enhanced by protein-bound $\mathrm{Cu}(\mathrm{I})$ [148].

On the other hand, detailed knowledge of the structural, affinity and binding features of $\mathrm{Cu}(\mathrm{I})$ to AS has been reported recently at single-residue resolution by an NMR-based study [149], where an excess of ascorbate was used to reduce AS-Cu(II) to AS-Cu(I). It had been shown previously that AS-Cu(II) complexes can be reduced directly by ascorbate [150], and high levels of this reductant agent are found in the intracellular milieu of neurons [147]. A series of 2D and $3 \mathrm{D}$ heteronuclear NMR experiments recorded in the presence of increasing concentrations of the metal ion revealed the presence of $\mathrm{Cu}(\mathrm{I})$ binding sites at the $\mathrm{N}$ - and $\mathrm{C}$-terminal regions of AS with different affinities (Fig. 7A) [149]. A comparative spectroscopic study involving the analysis of point-directed mutants and C-terminal truncated species of AS located the high affinity site in the vicinity of Met- 1 and Met- 5 residues (Fig. 7B). Lower affinity sites were identified around the sole His residue at position 50 and at the region comprising residues $115-130$ (Met residues are located at positions 116 and 127 of the C-terminus of AS).

The NMR-determined dissociation constant $\left(K_{d} \sim 2 \times 10^{-6} \mathrm{M}\right)$ for $\mathrm{Cu}(\mathrm{I})$ bound to the high affinity site is fully consistent with the well-documented binding of $\mathrm{Cu}(\mathrm{I})$ to a coordination environment that involves sulfur atoms of two or three Met residues [164-166]. Indeed, mass spectrometry of oxidative damage products indicates that $\mathrm{Cu}(\mathrm{II}) / \mathrm{Cu}(\mathrm{I})$ redox cycling catalyzes efficiently the oxidation of the ${ }^{1}$ MDVFMK ${ }^{6}$ peptide at the Met- 1 and Met-5 positions [149], as reported previously for AS peptide samples exposed to $\mathrm{Cu}(\mathrm{II})$ and hydrogen peroxide $[151,152]$.

Altogether, the data discussed here demonstrate conclusively that $\mathrm{AS}$ binds $\mathrm{Cu}(\mathrm{I})$ with relatively high affinity in a coordination environment that involves the sulfur atoms of Met- 1 and Met- 5 residues as the main anchoring moieties (Fig. 7B and C). Furthermore, in the presence of $\mathrm{O}_{2}$, the $\mathrm{Cu}(\mathrm{I})$ complex can catalyze the oxidation of Met-1 and Met-5 to methionine sulfoxide. Assuming that the dissociation constants reported for the high affinity $\mathrm{AS}-\mathrm{Cu}(\mathrm{II})$ site range between $10^{-10}$ and $10^{-9} \mathrm{M}$, the results discussed here indicate that the affinity of monomeric AS for $\mathrm{Cu}(\mathrm{I})$ is smaller than that for $\mathrm{Cu}(\mathrm{II})$. The different coordination environments of the copper ion in the two redox states might imply also a large reorganization energy. Detailed information on the kinetics of the AS- $\mathrm{Cu}(\mathrm{I}) / \mathrm{AS}-\mathrm{Cu}(\mathrm{II})$ redox process and its reactivity with dioxygen is thus required, in order to understand the role that AS-copper interactions play in the metal-mediated oxidative damage associated with the pathophysiology of PD.

\section{Biological implications and future directions}

This review presents a detailed structural description of the interactions of AS with divalent metal ions. The comparative analysis between $\mathrm{Cu}(\mathrm{II})$ and other divalent metal ions demonstrate conclusively a hierarchal effect of AS-metal interactions on AS 
(A)

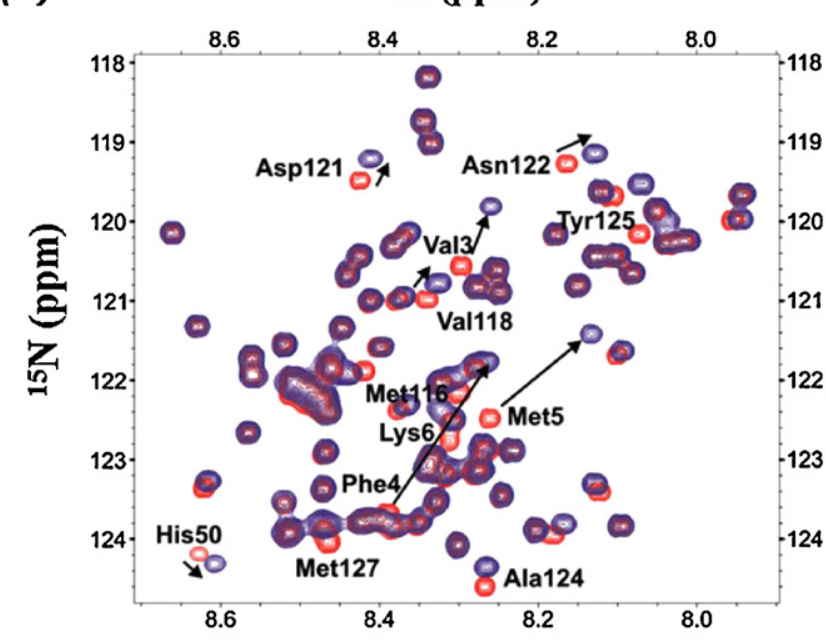

(B)

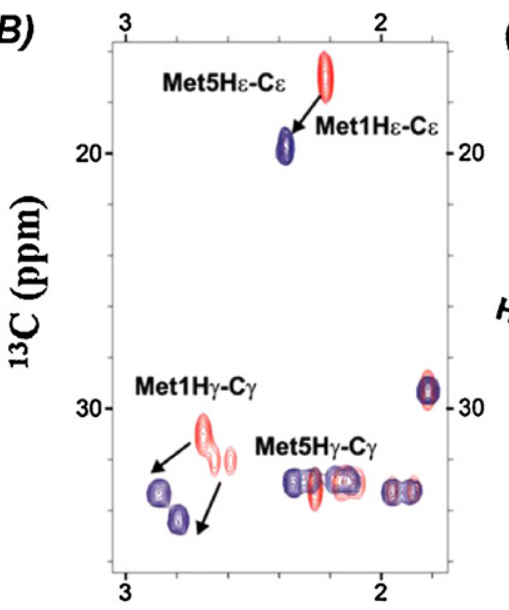

${ }^{1} \mathbf{H}$ (ppm)
(C)

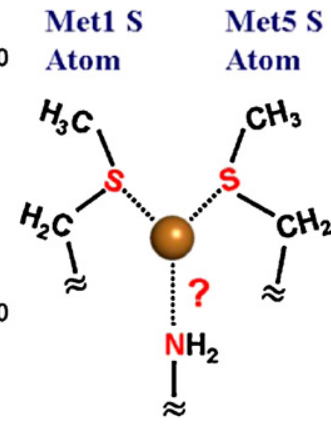

Met1 $\alpha \mathrm{NH}_{2}$ group

Fig. 7. NMR analysis of $\mathrm{Cu}(\mathrm{I})$ binding to AS. (A) Overlaid ${ }^{1} \mathrm{H}-{ }^{15} \mathrm{~N}$ HSQC spectra of wt AS in the absence (red) and presence of $\mathrm{Cu}(\mathrm{I})$ (blue). (B) Overlaid ${ }^{1} \mathrm{H}-{ }^{13} \mathrm{C}$ HSQC spectra of ${ }^{1} \mathrm{MDVFMK}^{6}$ AS peptide in the absence (red) and presence of $\mathrm{Cu}(\mathrm{I})$ (blue). The NMR assignments of those resonances affected significantly by the presence of the metal ion are indicated (labels and black arrows). (C) Schematic representation of $\mathrm{Cu}(\mathrm{I})$ coordination environment in the high affinity site of AS. The involvement of the $\alpha \mathrm{NH}_{2}$ group of Met-1 residue as metal ligand is currently under evaluation.

aggregation kinetics, dictated largely by structural factors corresponding to different protein regions. While divalent metal ions interact at a non-specific, low-affinity binding interface at the Cterminus of AS, copper binds with high affinity at the N-terminal region and it is the most effective metal ion in accelerating AS filament assembly. The structural characterization of copper coordination to AS and the affinity features of the protein-metal complexes formed have been also comprehensively discussed. Clearly, further research is needed on this area to reconcile the reported discrepancies; however, they do not obscure the fact the copper binding to AS is a highly specific event compared to other metal ions. The evidences reported indicate that the effect of copper on AS aggregation in vitro is not related neither to specific histidine binding nor to the general factor usually invoked for AS aggregation such as the interaction with clusters of negatively charged residues at the C-terminal region. Instead, the copper-enhanced AS amyloid formation is a direct consequence of the formation of the AS-copper complexes at the ${ }^{1}$ MDVFM $^{5}$ sequence, located at the $\mathrm{N}$-terminal region of the protein. Different mechanisms have been proposed for the amyloid-promoting effect exerted by divalent metal ions

on AS; among them, the site-specific copper catalyzed oxidation of AS, modulated by the direct coordination of $\mathrm{Cu}(\mathrm{II})$ and $\mathrm{Cu}(\mathrm{I})$ ions to the ${ }^{1} \mathrm{MD}^{2}$ and ${ }^{1} \mathrm{M}-\mathrm{M}^{5}$ motifs in the AS sequence mentioned above, appears as the most physiologically relevant to the onset of PD.

The development of the bioinorganic chemistry and structural biology of AS amyloid diseases in the last years has allowed researchers to perform a comparative analysis with other copperbinding proteins involved in neurodegenerative disorders. This analysis suggests that the interaction of AS with copper ions is likely to occur in vivo; indeed some researchers speculated also about a functional role of AS as a metalloprotein involved in metal homeostasis [167]. Strictly speaking, both AS and copper are highly abundant in brain tissue: AS accounts for approximately $1 \%$ of the total protein content in the striatum [126], while copper concentration in the brain is in the micromolar range [127]. Even if the intracellular copper pools are regulated by binding to ligands of various affinities, the coordination of copper these ligands is labile and subject to fluctuations under certain adverse circumstances [168]. According to the range of affinities reported for the AS-copper complexes, the concentration of copper in neurons under such adverse conditions might be sufficient to contribute to abnormal interactions with a highly abundant protein as AS, leading to neurodegeneration.

Future research must aim to add more biological significance to the prominent advances in the bioinorganic chemistry of AS; for instance, the role of copper ions has to be related to the molecular biology and biochemistry of PD. In order to unravel the role of this metal ion in AS aggregation, the coordination chemistry of copper bound to the several aggregation states accessible to AS has to be investigated; these include the proposed helically folded AS tetramer, the intrinsically disordered monomer, the tetramer/monomer bound to membranes, pre-fibrillar oligomeric species and fibrillar forms. As it is strictly related to these studies, future research has to be oriented to explore the redox chemistry accessible to these copper complexes in neurons (extracts or intact cells), and the possible mechanisms of toxicity associated with these species. Finally, the consequences of more complex scenarios (i.e. post-transductional modifications of AS) than those conceivable on the basis of the coordination chemistry of individual metal ions needs to be explored. Indeed, it has been reported that in vitro phosphorylation of AS and synthetic peptides based on the C-terminal sequence of the protein influences the affinity for metal ions such as $\mathrm{Fe}(\mathrm{II}) / \mathrm{Fe}(\mathrm{III})$ and $\mathrm{Al}(\mathrm{III})$ [169-171]. Re-evaluation of these conclusions under more physiologically relevant conditions would be then highly desirable.

These fascinating possibilities will face the test of scientific challenge in the next few years, but could relocate biometals such as copper from their current positions of marginal interest in neuroscience toward a much more mainstream position.

\section{Acknowledgements}

C.O.F. thanks ANPCyT, MINCyT, CONICET, Max Planck Society and the Alexander von Humboldt Foundation for financial support. C.O.F. is the head of a Partner Group of the Max Planck Institute for Biophysical Chemistry (Göttingen). L.Q. thanks CONACYT (CB2009128255 ) for financial support. C.W.B. is the recipient of a FP7 Marie Curie IEF grant.

\section{References}

[1] C.M. Dobson, Semin. Cell Dev. Biol. 15 (2004) 3.

[2] F. Chiti, C.M. Dobson, Annu. Rev. Biochem. 75 (2006) 333.

[3] L.M. Luheshi, D.C. Crowther, C.M. Dobson, Curr. Opin. Chem. Biol. 12 (2008) 25.

[4] F.H. Lewy, Handbuch der Neurologie, Springer-Verlag, Berlin, Germany, 1912. [5] L.S. Forno, J. Neuropathol. Exp. Neurol. 55 (1996) 259. 
[6] M. Goedert, Nat. Rev. Neurosci. 2 (2001) 492.

[7] M.G. Spillantini, M.L. Schmidt, V.M. Lee, J.Q. Trojanowski, R. Jakes, M. Goedert, Nature 388 (1997) 839.

[8] M.G. Spillantini, R.A. Crowther, R. Jakes, M. Hasegawa, M. Goedert, Proc. Natl. Acad. Sci. U. S. A. 95 (1998) 6469.

[9] R. Kruger, W. Kuhn, T. Muller, D. Woitalla, M. Graeber, S. Kosel, H. Przuntek, J.T. Epplen, L. Schols, O. Riess, Nat. Genet. 18 (1998) 106.

[10] M.H. Polymeropoulos, C. Lavedan, E. Leroy, S.E. Ide, A. Dehejia, A. Dutra, B. Pike, H. Root, J. Rubenstein, R. Boyer, E.S. Stenroos, S. Chandrasekharappa, A. Athanassiadou, T. Papapetropoulos, W.G. Johnson, A.M. Lazzarini, R.C. Duvoisin, G. Di Iorio, L.I. Golbe, R.L. Nussbaum, Science 276 (1997) 2045.

[11] J.J. Zarranz, J. Alegre, J.C. Gomez-Esteban, E. Lezcano, R. Ros, I. Ampuero, L. Vidal, J. Hoenicka, O. Rodriguez, B. Atares, V. Llorens, E. Gomez Tortosa, T. del Ser, D.G. Munoz, J.G. de Yebenes, Ann. Neurol. 55 (2004) 164.

[12] I. Martin, V.L. Dawson, T.M. Dawson, Annu. Rev. Genomics Hum. Genet. 12 (2011) 301.

[13] A.B. Singleton, M. Farrer, J. Johnson, A. Singleton, S. Hague, J. Kachergus, M. Hulihan, T. Peuralinna, A. Dutra, R. Nussbaum, S. Lincoln, A. Crawley, M. Hanson, D. Maraganore, C. Adler, M.R. Cookson, M. Muenter, M. Baptista, D. Miller, J. Blancato, J. Hardy, K. Gwinn-Hardy, Science 302 (2003) 841.

[14] M.B. Feany, W.W. Bender, Nature 404 (2000) 394.

[15] S. Hamamichi, R.N. Rivas, A.L. Knight, S. Cao, K.A. Caldwell, G.A. Caldwell, Proc. Natl. Acad. Sci. U. S. A. 105 (2008) 728.

[16] M. Hashimoto, E. Rockenstein, M. Mante, L. Crews, P. Bar-On, F.H. Gage, R. Marr, E. Masliah, Gene Ther. 11 (2004) 1713

[17] E. Masliah, E. Rockenstein, I. Veinbergs, M. Mallory, M. Hashimoto, A. Takeda, Y. Sagara, A. Sisk, L. Mucke, Science 287 (2000) 1265

[18] R. Bussell Jr., D. Eliezer, J. Mol. Biol. 329 (2003) 763.

[19] S. Chandra, X. Chen, J. Rizo, R. Jahn, T.C. Sudhof, J. Biol. Chem. 278 (2003) 15313.

[20] C.C. Jao, A. Der-Sarkissian, J. Chen, R. Langen, Proc. Natl. Acad. Sci. U. S. A. 101 (2004) 8331.

[21] B.I. Giasson, I.V. Murray, J.Q. Trojanowski, V.M. Lee, J. Biol. Chem. 276 (2001) 2380.

[22] R.A. Crowther, R. Jakes, M.G. Spillantini, M. Goedert, FEBS Lett. 436 (1998) 309.

[23] C.O. Fernandez, W. Hoyer, M. Zweckstetter, E.A. Jares-Erijman, V. Subramaniam, C. Griesinger, T.M. Jovin, EMBO J. 23 (2004) 2039.

[24] W. Hoyer, D. Cherny, V. Subramaniam, T.M. Jovin, Biochemistry 43 (2004) 16233.

[25] C.W. Bertoncini, Y.S. Jung, C.O. Fernandez, W. Hoyer, C. Griesinger, T.M. Jovin, M. Zweckstetter, Proc. Natl. Acad. Sci. U. S. A. 102 (2005) 1430.

[26] M.M. Dedmon, K. Lindorff-Larsen, J. Christodoulou, M. Vendruscolo, C.M. Dobson, J. Am. Chem. Soc. 127 (2005) 476.

[27] J.C. Lee, H.B. Gray, J.R. Winkler, J. Am. Chem. Soc. 127 (2005) 16388.

[28] J.C. Lee, B.T. Lai, J.J. Kozak, H.B. Gray, J.R. Winkler, J. Phys. Chem. B 111 (2007) 2107.

[29] T. Bartels, J.G. Choi, D.J. Selkoe, Nature 477 (2011) 107.

[30] W. Wang, I. Perovic, J. Chittuluru, A. Kaganovich, L.T. Nguyen, J. Liao, J.R. Auclair, D. Johnson, A. Landeru, A.K. Simorellis, S. Ju, M.R. Cookson, F.J. Asturias, J.N. Agar, B.N. Webb, C. Kang, D. Ringe, G.A. Petsko, T.C. Pochapsky, Q.Q. Hoang, Proc. Natl. Acad. Sci. U. S. A. 108 (2011) 17797

[31] B. Fauvet, M.K. Mbefo, M.B. Fares, C. Desobry, S. Michael, M.T. Ardah, E. Tsika, P. Coune, M. Prudent, N. Lion, D. Eliezer, D.J. Moore, B. Schneider, P. Aebischer, O.M. El-Agnaf, E. Masliah, H.A. Lashuel, J. Biol. Chem. 287 (2012) 15345.

[32] J. Burre, M. Sharma, T. Tsetsenis, V. Buchman, M.R. Etherton, T.C. Sudhof, Science 329 (2010) 1663.

[33] S. Chandra, G. Gallardo, R. Fernandez-Chacon, O.M. Schluter, T.C. Sudhof, Cell 123 (2005) 383.

[34] V.M. Nemani, W. Lu, V. Berge, K. Nakamura, B. Onoa, M.K. Lee, F.A. Chaudhry, R.A. Nicoll, R.H. Edwards, Neuron 65 (2010) 66.

[35] R. Bussell Jr., T.F. Ramlall, D. Eliezer, Protein Sci. 14 (2005) 862.

[36] T.S. Ulmer, A. Bax, N.B. Cole, R.L. Nussbaum, J. Biol. Chem. 280 (2005) 9595.

[37] S. Yu, K. Ueda, P. Chan, Mol. Neurobiol. 31 (2005) 243.

[38] R.G. Perez, J.C. Waymire, E. Lin, J.J. Liu, F. Guo, M.J. Zigmond, J. Neurosci. 22 (2002) 3090.

[39] R. Tehranian, S.E. Montoya, A.D. Van Laar, T.G. Hastings, R.G. Perez, J. Neurochem. 99 (2006) 1188.

[40] J. Xu, S.Y. Kao, F.J. Lee, W. Song, L.W. Jin, B.A. Yankner, Nat. Med. 8 (2002) 600.

[41] H.A. Lashuel, D. Hartley, B.M. Petre, T. Walz, P.T. Lansbury Jr., Nature 418 (2002) 291.

[42] H.A. Lashuel, B.M. Petre, J. Wall, M. Simon, R.J. Nowak, T. Walz, P.T. Lansbury Jr., J. Mol. Biol. 322 (2002) 1089.

[43] B. Caughey, P.T. Lansbury, Annu. Rev. Neurosci. 26 (2003) 267.

[44] C. Haass, H. Steiner, Nat. Neurosci. 4 (2001) 859.

[45] M.R. Cookson, M. van der Brug, Exp. Neurol. 209 (2008) 5.

[46] H. Olzscha, S.M. Schermann, A.C. Woerner, S. Pinkert, M.H. Hecht, G.G. Tartaglia, M. Vendruscolo, M. Hayer-Hartl, F.U. Hartl, R.M. Vabulas, Cell 144 (2011) 67.

[47] E. Gaggelli, H. Kozlowski, D. Valensin, G. Valensin, Chem. Rev. 106 (2006) 1995.

[48] H. Kozlowski, D. Brown, G. Valensin, Metallochemistry of Neurodegeneration: Biological, Chemical, and Genetic Aspects, RSC Publishing, Cambridge, UK, 2007.

[49] D.R. Brown, F. Hafiz, L.L. Glasssmith, B.S. Wong, I.M. Jones, C. Clive, S.J. Haswell, EMBO J. 19 (2000) 1180.
[50] D.R. Brown, H. Kozlowski, Dalton Trans. 13 (2004) 1907.

[51] E. Gaggelli, F. Bernardi, E. Molteni, R. Pogni, D. Valensin, G. Valensin, M. Remelli, M. Luczkowski, H. Kozlowski, J. Am. Chem. Soc. 127 (2005) 996.

[52] M. Klewpatinond, P. Davies, S. Bowen, D.R. Brown, J.H. Viles, J. Biol. Chem. 283 (2008) 1870

[53] D.R. Brown, Dalton Trans. 21 (2009) 4069

[54] P. Faller, C. Hureau, Dalton Trans. 7 (2009) 1080.

[55] J.W. Karr, V.A. Szalai, Biochemistry 47 (2008) 5006.

[56] N.H. Kim, J.K. Choi, B.H. Jeong, J.I. Kim, M.S. Kwon, R.I. Carp, Y.S. Kim, FASEB J 19 (2005) 783.

[57] M.A. Lovell, J.D. Robertson, W.J. Teesdale, J.L. Campbell, W.R. Markesbery, J. Neurol. Sci. 158 (1998) 47.

[58] S.C. Drew, C.L. Masters, K.J. Barnham, J. Am. Chem. Soc. 131 (2009) 8760

[59] S.C. Drew, C.J. Noble, C.L. Masters, G.R. Hanson, K.J. Barnham, J. Am. Chem. Soc. 131 (2009) 1195

[60] M. Klewpatinond, J.H. Viles, Biochem. J. 404 (2007) 393.

[61] T. Kowalik-Jankowska, M. Ruta, K. Wisniewska, L. Lankiewicz, J. Inorg. Biochem. 95 (2003) 270

[62] C.D. Syme, R.C. Nadal, S.E. Rigby, J.H. Viles, J. Biol. Chem. 279 (2004) 18169

[63] D. Valensin, M. Luczkowski, F.M. Mancini, A. Legowska, E. Gaggelli, G. Valensin K. Rolka, H. Kozlowski, Dalton Trans. 9 (2004) 1284

[64] D. Valensin, F.M. Mancini, M. Luczkowski, A. Janicka, K. Wisniewska, E. Gaggelli, G. Valensin, L. Lankiewicz, H. Kozlowski, Dalton Trans. 1 (2004) 16.

[65] J.H. Viles, F.E. Cohen, S.B. Prusiner, D.B. Goodin, P.E. Wright, H.J. Dyson, Proc Natl. Acad. Sci. U. S. A. 96 (1999) 2042.

[66] P. Dorlet, S. Gambarelli, P. Faller, C. Hureau, Angew. Chem. Int. Ed. Engl. 48 (2009) 9273.

[67] H. Eury, C. Bijani, P. Faller, C. Hureau, Angew. Chem. Int. Ed. Engl. 50 (2011) 901.

[68] C. Hureau, V. Balland, Y. Coppel, P.L. Solari, E. Fonda, P. Faller, J. Biol. Inorg Chem. 14 (2009) 995.

[69] C. Migliorini, E. Porciatti, M. Luczkowski, D. Valensin, Coord. Chem. Rev. 256 (2012) 352.

[70] E. Aronoff-Spencer, C.S. Burns, N.I. Avdievich, G.J. Gerfen, J. Peisach, W.E. Antholine, H.L. Ball, F.E. Cohen, S.B. Prusiner, G.L. Millhauser, Biochemistry 39 (2000) 13760

[71] B. Belosi, E. Gaggelli, R. Guerrini, H. Kozlowski, M. Luczkowski, F.M Mancini, M. Remelli, D. Valensin, G. Valensin, Chembiochem 5 (2004) 349.

[72] C.S. Burns, E. Aronoff-Spencer, C.M. Dunham, P. Lario, N.I. Avdievich, W.E. Antholine, M.M. Olmstead, A. Vrielink, G.J. Gerfen, J. Peisach, W.G. Scott, G.L. Millhauser, Biochemistry 41 (2002) 3991.

[73] M. Chattopadhyay, E.D. Walter, D.J. Newell, P.J. Jackson, E. Aronoff-Spencer, J Peisach, G.J. Gerfen, B. Bennett, W.E. Antholine, G.L. Millhauser, J. Am. Chem Soc. 127 (2005) 12647

[74] C.E. Jones, S.R. Abdelraheim, D.R. Brown, J.H. Viles, J. Biol. Chem. 279 (2004) 32018.

[75] F. Molina-Holgado, R.C. Hider, A. Gaeta, R. Williams, P. Francis, Biometals 20 (2007) 639.

[76] A.C. Badrick, C.E. Jones, Curr. Top. Med. Chem. 11 (2011) 543.

[77] D.T. Dexter, A. Carayon, F. Javoy-Agid, Y. Agid, F.R. Wells, S.E. Daniel, A.J. Lees, P. Jenner, C.D. Marsden, Brain 114 (Pt 4) (1991) 1953.

[78] R.J. Castellani, S.L. Siedlak, G. Perry, M.A. Smith, Acta Neuropathol. 100 (2000) 111.

[79] H.S. Pall, D.R. Blake, J.M. Gutteridge, A.C. Williams, J. Lunec, M. Hall, A. Taylor, Lancet 330 (1987) 238

[80] M.B. Youdim, D. Ben-Shachar, P. Riederer, Eur. Neurol. 31 (Suppl. 1) (1991) 34.

[81] W.H. Yu, Y. Matsuoka, I. Sziraki, A. Hashim, J. Lafrancois, H. Sershen, K.E. Duff, Neurochem. Res. 33 (2008) 902.

[82] W.R. Yu, H. Jiang, J. Wang, J.X. Xie, Neurosci. Bull. 24 (2008) 73.

[83] J.M. Gorell, C.C. Johnson, B.A. Rybicki, E.L. Peterson, G.X. Kortsha, G.G. Brown, R.J. Richardson, Neurotoxicology 20 (1999) 239.

[84] V.N. Uversky, J. Li, A.L. Fink, J. Biol. Chem. 276 (2001) 44284

[85] L. Breydo, J.W. Wu, V.N. Uversky, Biochim. Biophys. Acta 1822 (2012) 261.

[86] L. Breydo, V.N. Uversky, Metallomics 3 (2011) 1163.

[87] E. Sofic, A. Sapcanin, I. Tahirovic, I. Gavrankapetanovic, K. Jellinger, G.P. Reynolds, T. Tatschner, P. Riederer, J. Neural Transm. Suppl. 71 (2006) 39.

[88] M. Bisaglia, S. Mammi, L. Bubacco, J. Biol. Chem. 282 (2007) 15597.

[89] D. Allsop, J. Mayes, S. Moore, A. Masad, B.J. Tabner, Biochem. Soc. Trans. 36 (2008) 1293.

[90] B.J. Tabner, S. Turnbull, O. El-Agnaf, D. Allsop, Curr. Top. Med. Chem. 1 (2001) 507.

[91] B.J. Tabner, S. Turnbull, O.M. El-Agnaf, D. Allsop, Free Radic. Biol. Med. 32 (2002) 1076

[92] S. Turnbull, B.J. Tabner, O.M. El-Agnaf, S. Moore, Y. Davies, D. Allsop, Free Radic Biol. Med. 30 (2001) 1163

[93] N. Ostrerova-Golts, L. Petrucelli, J. Hardy, J.M. Lee, M. Farer, B. Wolozin, J. Neurosci. 20 (2000) 6048.

[94] M. Hashimoto, E. Rockenstein, L. Crews, E. Masliah, Neuromol. Med. 4 (2003)

[95] N.B. Cole, D.D. Murphy, J. Lebowitz, L. Di Noto, R.L. Levine, R.L. Nussbaum, J Biol. Chem. 280 (2005) 9678.

[96] R. Lowe, D.L. Pountney, P.H. Jensen, W.P. Gai, N.H. Voelcker, Protein Sci. 13 (2004) 3245.

[97] S.R. Paik, H.J. Shin, J.H. Lee, C.S. Chang, J. Kim, Biochem. J. 340 (1999) 821. 
[98] A. Binolfi, R.M. Rasia, C.W. Bertoncini, M. Ceolin, M. Zweckstetter, C. Griesinger, T.M. Jovin, C.O. Fernandez, J. Am. Chem. Soc. 128 (2006) 9893.

[99] G.R. Lamberto, V. Torres-Monserrat, C.W. Bertoncini, X. Salvatella, M. Zweckstetter, C. Griesinger, C.O. Fernandez, J. Biol. Chem. 286 (2011) 32036

[100] R.M. Rasia, C.W. Bertoncini, D. Marsh, W. Hoyer, D. Cherny, M. Zweckstetter, C. Griesinger, T. Jovin, C.O. Fernández, Proc. Natl. Acad. Sci. U. S. A. 102 (2005) 4294.

[101] J.C. Lee, H.B. Gray, J.R. Winkler, J. Am. Chem. Soc. 130 (2008) 6898.

[102] Y.H. Sung, C. Rospigliosi, D. Eliezer, Biochim. Biophys. Acta 1764 (2006) 5

[103] S.T. Hsu, C.W. Bertoncini, C.M. Dobson, J. Am. Chem. Soc. 131 (2009) 7222

[104] A. Binolfi, G.R. Lamberto, R. Duran, L. Quintanar, C.W. Bertoncini, J.M. Souza, C. Cervenansky, M. Zweckstetter, C. Griesinger, C.O. Fernandez, J. Am. Chem. Soc. 130 (2008) 11801

[105] A. Binolfi, E.E. Rodriguez, D. Valensin, N. D’Amelio, E. Ippoliti, G. Obal, R. Duran, A. Magistrato, O. Pritsch, M. Zweckstetter, G. Valensin, P. Carloni, L. Quintanar, C. Griesinger, C.O. Fernandez, Inorg. Chem. 49 (2010) 10668.

[106] P.G. Daniele, E. Prenesti, G. Ostacoli, J. Chem. Soc. Dalton Trans. (1996) 3269

[107] H. Sigel, R.B. Martin, Chem. Rev. 82 (1982) 385.

[108] E.E. Bernanducci, W.F. Schwindinger, J.L. Hughey, K. Krogh-Jespersen, H.J Schugar, J. Am. Chem. Soc. 103 (1981) 1686.

[109] T.G. Fawcett, E.E. Bernanducci, K. Krogh-Jespersen, H.J. Schugar, J. Am. Chem. Soc. 102 (1980) 2598.

[110] M.S. Jackson, J.C. Lee, Inorg. Chem. 48 (2009) 9303.

[111] H.R. Lucas, J.C. Lee, J. Inorg. Biochem. 104 (2010) 245.

[112] M. Bortolus, M. Bisaglia, A. Zoleo, M. Fittipaldi, M. Benfatto, L. Bubacco, A.L. Maniero, J. Am. Chem. Soc. 132 (2010) 18057.

[113] S.C. Drew, S.L. Leong, C.L. Pham, D.J. Tew, C.L. Masters, L.A. Miles, R. Cappai, K.J. Barnham, J. Am. Chem. Soc. 130 (2008) 7766.

[114] C.G. Dudzik, E.D. Walter, G.L. Millhauser, Biochemistry 50 (2011) 1771.

[115] J. Peisach, W.B. Mims, Eur. J. Biochem. 84 (1978) 207.

[116] A. Ahmad, C.S. Burns, A.L. Fink, V.N. Uversky, J. Biomol. Struct. Dyn. 29 (2012) 825.

[117] S.C. Drew, D.J. Tew, C.L. Masters, R. Cappai, K.J. Barnham, Appl. Magn. Reson. 36 (2009) 223.

[118] T. Kowalik-Jankowska, A. Rajewska, E. Jankowska, Z. Grzonka, Dalton Trans. 42 (2006) 5068.

[119] D. Valensin, F. Camponeschi, M. Luczkowski, M.C. Baratto, M. Remelli, G. Valensin, H. Kozlowski, Metallomics 3 (2011) 292.

[120] T. Kowalik-Jankowska, A. Rajewska, K. Wisniewska, Z. Grzonka, J. Jezierska, J. Inorg. Biochem. 99 (2005) 2282.

[121] C. Kallay, K. Varnagy, G. Micera, D. Sanna, I. Sovago, J. Inorg. Biochem. 99(2005) 1514.

[122] D. Sanna, C.G. Agoston, G. Micera, I. Sovago, Polyhedron 20 (2001) 3079

[123] C. Hureau, Y. Coppel, P. Dorlet, P.L. Solari, S. Sayen, E. Guillon, L. Sabater, P. Faller, Angew. Chem. Int. Ed. Engl. 48 (2009) 9522.

[124] J.W. Karr, V.A. Szalai, J. Am. Chem. Soc. 129 (2007) 3796.

[125] C. Hureau, C. Mathé, P. Faller, T.A. Mattioli, P. Dorlet, J. Biol. Inorg. Chem. 13 (2008) 1055.

[126] A. Iwai, E. Masliah, M. Yoshimoto, N. Ge, L. Flanagan, H.A. de Silva, A. Kittel, T. Saitoh, Neuron 14 (1995) 467.

[127] D.R. Brown, K. Qin, J.W. Herms, A. Madlung, J. Manson, R. Strome, P.E. Fraser, T. Kruck, A. von Bohlen, W. Schulz-Schaeffer, A. Giese, D. Westaway, H. Kretzschmar, Nature 390 (1997) 684.

[128] L. Hong, J.D. Simon, J. Phys. Chem. B 113 (2009) 9551.

[129] L. Hong, J.D. Simon, Metallomics 3 (2011) 262.

[130] Z.M. Anwar, H.A. Azab, J. Chem. Eng. Data 44 (1999) 1151

[131] M. Sokołowska, W. Bal, J. Inorg. Biochem. 99 (2005) 1653.

[132] V.N. Uversky, A.L. Fink, FEBS Lett. 522 (2002) 9.

[133] D.R. Brown, Biochem. Biophys. Res. Commun. 380 (2009) 377.

[134] P. Davies, X. Wang, C.J. Sarell, A. Drewett, F. Marken, J.H. Viles, D.R. Brown, Biochemistry 50 (2011) 37.
[135] V.N. Uversky, J. Li, A.L. Fink, J. Biol. Chem. 276 (2001) 10737.

[136] A.P. Garnett, J.H. Viles, J. Biol. Chem. 278 (2003) 6795.

[137] C.S. Atwood, G. Perry, H. Zeng, Y. Kato, W.D. Jones, K.Q. Ling, X. Huang, R.D. Moir, D. Wang, L.M. Sayre, M.A. Smith, S.G. Chen, A.I. Bush, Biochemistry 43 (2004) 560

[138] G.B. Irvine, O.M. El-Agnaf, G.M. Shankar, D.M. Walsh, Mol. Med. 14 (2008) 451.

[139] D.P. Smith, G.D. Ciccotosto, D.J. Tew, M.T. Fodero-Tavoletti, T. Johanssen, C.L. Masters, K.J. Barnham, R. Cappai, Biochemistry 46 (2007) 2881

[140] S.R. Paik, H.J. Shin, J.H. Lee, Arch. Biochem. Biophys. 378 (2000) 269.

[141] B.J. Tabner, O.M. El-Agnaf, M.J. German, N.J. Fullwood, D. Allsop, Biochem. Soc. Trans. 33 (2005) 1082.

[142] B.J. Tabner, O.M. El-Agnaf, S. Turnbull, M.J. German, K.E. Paleologou, Y. Hayashi, L.J. Cooper, N.J. Fullwood, D. Allsop, J. Biol. Chem. 280 (2005) 35789.

[143] B.J. Tabner, S. Turnbull, N.J. Fullwood, M. German, D. Allsop, Biochem. Soc. Trans. 33 (2005) 548.

[144] S. Turnbull, B.J. Tabner, D.R. Brown, D. Allsop, Biochemistry 42 (2003) 7675.

[145] C.B. Glaser, G. Yamin, V.N. Uversky, A.L. Fink, Biochim. Biophys. Acta 1703 (2005) 157

[146] V.N. Uversky, G. Yamin, P.O. Souillac, J. Goers, C.B. Glaser, A.L. Fink, FEBS Lett 517 (2002) 239

[147] L. Guilloreau, S. Combalbert, A. Sournia-Saquet, H. Mazarguil, P. Faller, Chembiochem 8 (2007) 1317

[148] H.R. Lucas, S. Debeer, M.S. Hong, J.C. Lee, J. Am. Chem. Soc. 132 (2010) 6636

[149] A. Binolfi, A.A. Valiente-Gabioud, R. Duran, M. Zweckstetter, C. Griesinger, C.O. Fernandez, J. Am. Chem. Soc. 133 (2011) 194.

[150] C. Wang, L. Liu, L. Zhang, Y. Peng, F. Zhou, Biochemistry 49 (2010) 8134.

[151] T. Kowalik-Jankowska, A. Rajewska, E. Jankowska, Z. Grzonka, Dalton Trans. 6 (2008) 832 .

[152] T. Kowalik-Jankowska, A. Rajewska, E. Jankowska, K. Wisniewska, Z. Grzonka, J. Inorg. Biochem. 100 (2006) 1623.

[153] H. Bayir, A.A. Kapralov, J. Jiang, Z. Huang, Y.Y. Tyurina, V.A. Tyurin, Q. Zhao, N.A. Belikova, I.I. Vlasova, A. Maeda, J. Zhu, H.M. Na, P.G. Mastroberardino, L.J. Sparvero, A.A. Amoscato, C.T. Chu, J.T. Greenamyre, V.E. Kagan, J. Biol. Chem. 284 (2009) 15951.

[154] M. Hashimoto, L.J. Hsu, Y. Xia, A. Takeda, A. Sisk, M. Sundsmo, E. Masliah, Neuroreport 10 (1999) 717.

[155] A. Olteanu, G.J. Pielak, Protein Sci. 13 (2004) 2852.

[156] X.H. Yang, H.C. Huang, L. Chen, W. Xu, Z.F. Jiang, J. Alzheimers Dis. 18 (2009) 799.

[157] S.S. Hindo, A.M. Mancino, J.J. Braymer, Y. Liu, S. Vivekanandan, A. Ramamoorthy, M.H. Lim, J. Am. Chem. Soc. 131 (2009) 16663.

[158] P. Faller, Chembiochem 10 (2009) 2837.

[159] J. Shearer, P.E. Callan, T. Tran, V.A. Szalai, Chem. Commun. (Camb.) 46 (2010) 9137.

[160] J. Shearer, V.A. Szalai, J. Am. Chem. Soc. 130 (2008) 17826.

[161] S. Furlan, C. Hureau, P. Faller, G. La, Penna, J. Phys. Chem. B 114 (2010) 15119.

[162] H.A. Feaga, R.C. Maduka, M.N. Foster, V.A. Szalai, Inorg. Chem. 50 (2011) 1614

[163] B. Alies, B. Badei, P. Faller, C. Hureau, Chemistry 18 (2012) 1161.

[164] J. Jiang, I.A. Nadas, M.A. Kim, K.J. Franz, Inorg. Chem. 44 (2005) 9787.

[165] J.T. Rubino, M.P. Chenkin, M. Keller, P. Riggs-Gelasco, K.J. Franz, Metallomics 3 (2011) 61.

[166] J.T. Rubino, P. Riggs-Gelasco, K.J. Franz, J. Biol. Inorg. Chem. 15 (2010) 1033

[167] P. Davies, D. Moualla, D.R. Brown, PLoS One 6 (2011) e15814.

[168] M.L. Schlief, J.D. Gitlin, Mol. Neurobiol. 33 (2006) 81.

[169] L.L. Liu, K.J. Franz, J. Am. Chem. Soc. 127 (2005) 9662.

[170] L.L. Liu, K.J. Franz, J. Biol. Inorg. Chem. 12 (2007) 234

[171] Y. Lu, M. Prudent, B. Fauvet, H.A. Lashuel, H.H. Girault, ACS Chem. Neurosci. 2 (2011) 667 